Federal Reserve Bank of Dallas

Globalization and Monetary Policy Institute

Working Paper No. 156

http://www.dallasfed.org/assets/documents/institute/wpapers/2013/0156.pdf

\title{
Why are Goods and Services more Expensive in Rich Countries? Demand Complementarities and Cross-Country Price Differences
}

\author{
Daniel P. Murphy \\ Darden School of Business, University of Virginia
}

September 2013

\begin{abstract}
Empirical studies show that tradable consumption goods are more expensive in rich countries. This paper proposes a simple yet novel explanation for this apparent failure of the law of one price: Consumers' utility from tradable goods depends on their consumption of complementary goods and services. Monopolistically competitive firms charge higher prices in countries with more complementary goods and services because consumer demand is less elastic there. The paper embeds this explanation within a static Krugman (1980)-style model of international trade featuring differentiated tradable goods. Extended versions of the model can also account for the high prices of nontradable services in rich countries. The paper provides direct evidence in support of this new explanation. Using free-alongside-ship prices of U.S. and Chinese exports, I demonstrate that prices of specific subsets of tradable goods are higher in countries with high consumption of relevant complementary goods, conditional on per capita income and other country-level determinants of consumer goods prices.
\end{abstract}

JEL codes: E31, F12, F14, L11

\footnotetext{
* Daniel P. Murphy, Darden School of Business, Charlottesville, VA 22906-6550. 303-884-5037. murphyd@darden.virginia.edu. I am incredibly grateful to Alan Deardorff, Lutz Kilian, and Andrei Levchenko for their guidance and to Jagadeesh Sivadasan and Michael Olabisi for sharing the Chinese export data. Thanks also to Dan Ackerberg, Jonathan Eaton, Yuriy Gorodnichenko, Andrew McCallum, Philip Sauré, Ina Simonovska, Martin Strieborny, Lucia Tajoli, Alberto Trejos, Jing Zhang, and seminar participants at Michigan, Dartmouth, Virginia, Federal Reserve Board, Miami, UCSD, UBC, and Penn State for helpful comments and discussions. The views in this paper are those of the author and do not necessarily reflect the views of the Federal Reserve Bank of Dallas or the Federal Reserve System.
} 


\section{Introduction}

There is abundant evidence that tradable goods are more expensive in countries with high percapita incomes. In particular, recent studies of disaggregate data on tradable goods show a failure of the law of one price due to firms charging higher markups for goods sold to rich countries than for goods sold to poor countries. For example, Alessandria and Kaboski (2011) find that rich countries pay more for goods leaving U.S. docks, and Simonovska (2013) documents that an online apparel retailer charges higher markups to consumers in rich countries.

Additional empirical work corroborates this evidence of a failure of the law of one price for tradables. Gopinath, Gourinchas, Hsieh, and Li (2011) demonstrate that wholesalers charge different markups in the U.S. market than in the Canadian market. Fitzgerald and Haller (2012) and Burstein and Jaimovich (2012) also find that wholesale prices differ substantially across destinations, even when the products are made in the same plant. Their evidence suggests that cross-country price differences are driven by characteristics specific to the destination countries, and motivates further research to understand the precise nature of these destination-country characteristics.

Recent work proposes theoretical explanations to account for the high prices of tradables in rich countries. For example, Alessandria and Kaboski (2011) suggest that consumers in rich countries are unaware of price differences across retail locations and have a high opportunity cost of searching for price discounts. However, support for existing theories is indirect and primarily based on the ability of calibrated models to match the data. This paper proposes a new explanation for high prices in rich countries, and provides direct empirical support for the proposed mechanism.

The new theoretical explanation is based on a high (and inelastic) demand in rich countries arising from high consumption of goods and services that complement demand for tradable goods. Specifically, the utility a consumer derives from tradable goods depends on his consumption of other goods and services that complement the tradable goods. Higher utility from tradable goods lowers the price elasticity of demand for tradables, causing monopolistically competitive firms to charge higher markups in markets with high consumption of complementary goods and services. Since consumers in rich countries can afford more complementary goods and services, they have a lower price-elasticity of demand for tradable consumer goods and are charged higher prices for tradables. 
One example of such a complementary good is housing, which complements the demand for consumer tradables such as a home entertainment system. In the U.S., consumers have relatively inelastic demand for home entertainment systems because they also have spacious TV rooms in their homes and a reliable supply of energy. In Ecuador, in contrast, the average consumer has less space in his home and an unreliable power supply. Firms can therefore charge a higher price in the U.S. than in Ecuador for identical entertainment systems.

Demand for new consumer goods also depends on public infrastructure, including roads and public safety. The value of a car, for example, depends not only on features specific to the vehicle, but also on the environment in which the car is driven. Paved roads increase the utility from owning a nice car, as does a safe environment with low probability of the car being stolen, while owning the same car may provide far less utility in an area with dirt roads or in an area that is insecure.

Many types of goods and services may complement demand for differentiated consumer goods (and differentiated consumer goods could complement demand for each other). To distinguish the complementary goods from the consumer goods in the analysis below, I refer to these complementary goods and services as catalyst goods. Often catalyst goods will be durables, such as housing or public infrastructure, but they may also be services or intangibles, such as public safety, or other consumer goods. The term catalyst captures the notion that some goods and services facilitate consumers' derivation of utility from other final goods and services. The notion of catalysts is similar to the notion of consumer demand proposed by Lancaster (1966), who suggests that goods and services are not direct objects of utility themselves but rather contain properties and characteristics that consumers combine to generate utility.

This explanation based on demand complementarity and pricing-to-market is simple, but to my knowledge has not been explored to date. ${ }^{1}$ Below I embed this explanation within a general equilibrium model that builds on a class of utility functions developed in the trade literature that yield demand curves with nonconstant price elasticities of demand. The model features demand complementarity between catalyst goods and differentiated final consumption goods. Specifically, the intercept of the demand curve for a differentiated final good depends on the level of consumption of catalyst goods. Section 2 develops the basic intuition within a closed

\footnotetext{
${ }^{1}$ The term pricing-to-market refers to general price discrimination across countries. Krugman (1987) defines pricing-to-market as price discrimination in response to nominal exchange rate movements. A number of authors since then, including Alessandria and Kaboski (2011), refer to the term more generally.
} 
economy and demonstrates that as the country's income increases, it consumes more catalyst goods and pays higher prices for differentiated consumer goods. Section 3 extends the analysis to two countries with the aim of explaining the relevant empirical facts with respect to prices of tradable goods across countries. In equilibrium, the rich country consumes more catalyst goods and pays more for tradable goods.

The paper provides independent empirical evidence that that markups and prices of consumer goods depend on a country's consumption of the relevant catalyst goods and services. Specifically, I use U.S. and Chinese export data to investigate whether subsets of consumer goods are sold at higher prices to countries with higher stocks of relevant catalysts. I show that household goods and electronic goods are sold at higher prices to countries with more housing and electricity, conditional on per capita income and other country-level determinants of consumer goods prices. Also, new cars are sold at higher prices to countries with higher percentages of paved roads. An advantage of the empirical specification is that the strong estimated relationship is conditional on the association between catalyst consumption and prices that is captured by the country-level fixed effects, and thus provides lower bound on the dependence of prices on catalyst goods. Since catalyst consumption is strongly correlated with income per capita, the results also provide a lower bound on the dependence of consumer prices on income per capita driven by demand complementarities.

While the empirical support for demand complementarities in causing cross-country price differences is based on data for tradable goods, the intuition for why demand complementarities causes high prices is not limited to tradables; the same intuition applies to demand for nontradable goods and services. The typical explanation for the observed correlation between country per-capita income and nontradable prices is based on the theory developed by Harrod (1933), Balassa (1964), and Samuelson (1964), collectively referred to as HBS. The HBS model postulates that the law of one price holds in tradables, and that rich-country productivity is higher in the tradable sector than in the nontradable sector. High productivity in the tradable sector drives up wages in rich countries, which causes higher prices in the sector with lower productivity (nontradables).

As recently noted by Alessandria and Kaboski (2011), it is unlikely that HBS can fully explain the price-income relationship across countries because the difference between tradablesector productivity and nontradable-sector productivity within rich countries is too small to 
account for the strong relationship between nontradable prices and incomes across countries. Section 4 demonstrates that demand complementarities can offer an additional explanation for the relationship between prices of services and income per capita without relying on sectoral productivity differences. In the extended model that incorporates differentiated nontradable goods, high consumption of catalyst goods (e.g., housing, roads, public safety, or any other complementary good) is associated with high demand for nontradable goods and a low price elasticity of demand.

Thus demand complementarities and pricing-to-market can provide a unified explanation for cross-country price differences without relying on within-country productivity patterns for which there is limited empirical support, and the mechanism is directly supported by evidence from the micro data. ${ }^{2}$ Simonovska (2013) is the most closely related paper that offers an explanation for high prices of tradables in rich countries. ${ }^{3}$ In Simonovska's model, high tradable prices in rich countries are due to low demand elasticities (and corresponding high markups) arising from consumption of a larger set of varieties of imported goods. In the model presented below, high prices reflect high consumption of catalyst goods, rather than differences in the set of imported goods. Furthermore, demand complementarity and pricing-to-market causes high prices in a closed economy setting as well as in an open economy setting and can account for a number of empirical regularities in the trade and growth literatures. Thus, while both the model in Simonovska (2013) and the model here employ forms of nonhomothetic preferences that permit price-dependent demand elasticities, the underlying mechanisms are different. One implication of the demand-complementarities explanation is that the extent to which markups vary across countries should depend on the extent to which the tradable good in question is complementary to other goods and services.

The demand-side explanation for high prices of consumer goods in rich countries explored here complements a burgeoning literature that examines demand-side explanations for the cross-country relationship between income and quality of imports. ${ }^{4}$ Fajgelbaum, Grossman,

\footnotetext{
${ }^{2}$ As demonstrated in Murphy (2013), demand complementarities can also account for patterns of investment rates and investment prices, and offers a possible resolution to the productivity puzzle identified by Hsieh and Klenow (2007).

${ }^{3}$ Hummels and Lugovsky (2009) and Alessandria and Kaboski (2011) also propose theoretical explanations for the positive correlation between markups and income per capita.

${ }^{4}$ This paper more broadly fits into work that explores the implications of nonhomothetic preferences for patterns of trade, including Bergstrand (1990), Hunter (1991), Matsuyama (2000), Mitra and Trindade (2005) and Fieler (2011),
} 
and Helpman (2011) develop a model featuring complementarity between a homogenous good and quality of vertically differentiated goods. In their model, higher incomes are associated with more purchases of higher quality goods, but not with higher markups paid for those goods. An interesting avenue for future research is to develop models in which high consumption of catalyst goods is associated with purchases of higher quality goods and higher markups for a good of any given quality.

The remainder of the paper proceeds as follows. Section 2 embeds demand complementarities in a closed-economy model to demonstrate in a simple setting how prices and markups increase with income through the effect of demand complementarities. Section 3 develops a two-country model to explicitly demonstrate that the proposed mechanism can account for the high prices of tradable goods in rich countries. Section 4 extends the twocountry model to incorporate differentiated nontradable goods. Section 5 presents the empirical evidence that demonstrates the dependence of prices on catalyst consumption across countries. Section 6 offers a discussion of the interpretation of catalyst goods, and of the quantitative significance of the proposed mechanism. Section 7 concludes.

\section{Closed Economy Model}

This section illustrates in a closed-economy setting how prices of consumer goods increase with a country's wealth due to markups that rise with the country's stock of catalyst goods. The closed economy features a representative consumer with preferences over differentiated final goods, a homogenous catalyst good, and a homogenous numeraire good. The final goods represent appliances, household items, and cars, among other consumer goods. The homogenous catalyst good represents housing and public infrastructure such as roads, energy supply, safety, and any other good that may complement demand for the final goods.

The catalyst is produced under perfect competition by a representative firm, while the consumer goods are produced by monopolistically competitive firms. Both sectors use labor, which is supplied inelastically, as the only factor of production. The numeraire is endowed to the economy and enters the consumer's utility function linearly. This particular setup is based on a variant of the linear demand system developed by Ottaviano, Tabuchi, and Thisse (2002), and

among many others. Markusen (2013) reviews the literature and discusses a range of phenomena for which nonhomothetic preferences improve the correspondence between trade models and the data. 
is chosen to demonstrate in the simplest possible setting how demand complementarities and pricing-to-market cause prices of final consumer goods to rise with a country's wealth. The Ottaviano et al (2002) demand system is analytically convenient, in part because the marginal utility of income is unity for all levels of income. Appendix A demonstrates that the results of this section are robust to alternative specifications for which the marginal utility of income varies with income and the numeraire is produced with labor.

Model Setup. The representative agent's utility function is defined over the catalyst good $C$, the mass $\Omega$ of final goods, and a numeraire $y$ :

$$
U=y+C^{\alpha} \int_{\Omega} f_{\omega} d \omega-\frac{1}{2} \gamma \int_{\Omega} f_{\omega}^{2} d \omega,
$$

where $f_{\omega}$ is consumption of final good $\omega \in \Omega$. The numeraire $y$ is endowed to the economy, and could represent any commodity, such as gold or wheat. Agricultural commodities are perhaps the most intuitive interpretation of the numeraire because, among other reasons, agriculture is often considered to be endowed to the economy due to its heavy reliance on immobile factors of production. $^{5}$

Equation (1) is a simplified version of the utility functions used in Ottaviano et al (2002), Melitz and Ottaviano (2008), and Foster, Haltiwanger, and Syverson (2008). The utility function here differs from their utility functions in two ways. First, the marginal utility from consuming any variety $\omega$ is independent of consumption of any other variety $\omega^{\prime} \neq \omega$. This is for analytical convenience only. Second, equation (1) features a catalyst good $C$ that acts as a demand shifter for the consumption goods.

The agent inelastically supplies $L$ units of labor to the market. The agent also owns the firms in the economy and receives profit income from the mass $\Omega$ of firms that produce differentiated consumption goods. The budget constraint is

$$
y+w L+\int_{\Omega} \Pi_{\omega} d \omega=y+p_{C} C+\int_{\Omega} p_{\omega} f_{\omega} d \omega,
$$

where $w$ is the wage, $p_{C}$ is the price of the catalyst, and $p_{\omega}$ is the price of variety $\omega$.

Maximizing (1) subject to (2) yields demand for final good $f_{\omega}$ :

$$
f_{\omega}^{d}=\frac{1}{\gamma}\left(C^{\alpha}-p_{\omega}\right)
$$

\footnotetext{
${ }^{5}$ See, for example Ottaviano et al (2002), and, more recently, Allen (2012) for models with an endowed agricultural commodity.
} 
which is increasing in $C$. This simple linear demand function captures the notion that demand for consumption goods is less elastic when the economy has a higher stock of housing and public infrastructure. For example, a consumer's willingness to pay for a fancy new oven is higher (and his price-sensitivity lower) if he has a nice kitchen and house that can accommodate dinner guests.

Demand for the catalyst is likewise increasing in consumption of final goods:

$$
C^{d}=\left(\frac{\alpha F}{p_{C}}\right)^{\frac{1}{1-\alpha}},
$$

where $F \equiv \int_{0}^{\Omega} f_{\omega} d \omega$. The larger the mass of goods $\Omega$, and the more of each good consumed, the higher is the demand for the catalyst. For example, demand for a mansion is high if a consumer has access to artwork, furniture, and appliances with which to fill the mansion. Otherwise a large, empty house is of little value.

Final Good Sector. Final good firms employ labor in a linear production function to produce output according to

$$
f_{\omega}=A L_{\omega}
$$

where $A$ is labor productivity, which is identical across firms and across sectors, and $L_{\omega}$ is the amount of labor employed by firm $\omega$. Each firm chooses its output price to maximize profits. Firm $\omega$ 's profit function is

$$
\Pi_{\omega}=p_{\omega} f_{\omega}-\frac{w}{A} f_{\omega} .
$$

The profit-maximizing price is derived by substituting (3) into (6) and maximizing with respect to $p_{\omega}$ :

$$
p_{\omega}=\frac{1}{2}\left(C^{\alpha}+\frac{w}{A}\right)
$$

Prices are increasing in $C$ because demand is less elastic when $C$ is high. Equation (7) captures the intuition that (a) monopolistically competitive firms charge a price that is proportional to consumer utility from consumption of firms' output, and (b) catalyst goods increase utility from consumption of final goods. The two-country counterpart to (7) in Section 3 derives the central result that rich countries pay higher prices for identical goods. Note that linearity of the demand curve (3) is sufficient but not necessary for the price elasticity of demand to be decreasing in the 
catalyst. Appendix B derives the necessary and sufficient conditions under which the price elasticity of demand is decreasing in $C$.

Given the price, demand for variety $\omega$ is

$$
f_{\omega}^{d}=\frac{1}{2 \gamma}\left(C^{\alpha}-\frac{w}{A}\right),
$$

which is derived by substituting (7) into (3). Firm $\omega$ earns profits given by

$$
\Pi_{\omega}=\frac{1}{4 \gamma}\left(C^{\alpha}-\frac{w}{A}\right)^{2} .
$$

I permit profits to be positive because incorporating a zero-profit condition would simply complicate the model by adding an equilibrium equation and an extra endogenous variable (the mass of final goods firms). Also, abstracting from fixed costs and increasing returns permits a clear comparison of productivity across sectors to demonstrate that demand complementarities, rather than productivity differentials, drive the price differences in the two-country models in sections 3 through 5. Nonetheless, the positive relationship between final goods prices and economic wealth derived below is robust to incorporating zero profits as a long-run equilibrium condition.

Since productivity is identical across firms, so are prices and quantities: $f_{\omega}=f$ and $p_{\omega}=$ $p \forall \omega \in \Omega$. Total demand over all final consumption goods is derived by integrating (8) across varieties:

$$
F=\frac{\Omega}{2 \gamma}\left(C^{\alpha}-\frac{w}{A}\right)
$$

Given total demand for final goods, we can write demand for labor in the final good sector as $L_{Q} \equiv \int_{0}^{\Omega} L_{\omega} d \omega$, or

$$
L_{Q}=\frac{1}{A} F
$$

Catalyst Sector. Catalysts are produced competitively using the technology

$$
C=A L_{C},
$$

where $L_{C}$ is labor in the catalyst sector. Cost minimization yields the price of catalysts, $p_{C}=$ $w / A$.

Equilibrium. Equilibrium is characterized by demand for catalysts (4), demand for consumer goods (9), and labor market clearing, 


$$
L=\frac{1}{A}(F+C)
$$

The endogenous variables are $F, C$, and $w$.

Comparative Statics. The central message of this section is that in general equilibrium, markups and prices of final goods are increasing in the economy's wealth. Figure 1 shows how market outcomes vary with productivity under the following parameterization:

$$
L=1, \quad A=1, \quad \Omega=1, \quad \alpha=0.3, \quad \gamma=0.3 .^{6}
$$

As $A$ increases, the price of the catalyst falls and the quantity of the catalyst increases. The increase in $C$ shifts out the demand curve for final goods, lowering the price-elasticity of demand. Firms charge a higher markup, causing a higher price of final goods. The positive effect of $C$ on demand for final goods outweighs the counteracting effect of the increase in $w$ on the price, so overall demand for final goods increases. Thus, even in this simple closed economy, prices and quantities of final goods rise with economy-wide productivity due to high demand from the consumption of more catalyst goods.

\section{Two-Country Model}

This section extends the model of Section 2 to incorporate trade between two countries $N$ (North) and $S$ (South). The purpose of this exercise is to demonstrate that demand complementarities and pricing-to-market can account for the evidence of higher prices of tradable goods in rich countries than in poor countries. In the model, each country is endowed with the numeraire and inelastically supplies labor to produce catalyst goods and differentiated final goods. Catalyst goods are not traded across countries. This assumption is for simplicity (the qualitative results are robust to permitting the catalyst to be traded), and because some catalyst goods represent housing and public infrastructure, which are fixed immobile assets. The numeraire is endowed to each country and is traded. Following Krugman (1980), each country specializes in a unique set of differentiated final goods. As in Section 2, final goods are produced by monopolistically competitive firms. Firms can move final goods costlessly across international borders. Consumers, however, face large costs of moving goods across international borders. Therefore even though firms charge country-specific prices, consumers do

\footnotetext{
${ }^{6}$ The qualitative results with respect to the markup are robust to all parameter values. A proof based on total differentiation of the equilibrium equations is available from the author upon request.
} 
not arbitrage because there are prohibitive costs associated with doing so. These costs could represent the time required to travel across international borders, as suggested in Gopinath et al (2011), as well as other transportation costs and information rigidities.

Model Setup. Each country $j \in\{N, S\}$ produces a mass $\Omega_{j}$ of final goods which are consumed at home and abroad. Goods produced in country $j$ are indexed by $\omega_{j} \in \Omega_{j}$. The utility function of the representative consumer in country $j$ is

$$
U_{j}=y_{j}+\sum_{i=N, S} \int_{\omega_{i} \in \Omega_{i}}\left[C_{j}^{\alpha} f_{j}\left(\omega_{i}\right)-\frac{\gamma}{2}\left(f_{j}\left(\omega_{i}\right)\right)^{2}\right] d \omega_{i},
$$

where $y_{j}$ and $C_{j}$ are consumption of the numeraire and catalyst by country $j$ and $f_{j}\left(\omega_{i}\right)$ is consumption in country $j$ of variety $\omega_{i}$ from country $i \in\{N, S\}$. As in the previous section, the numeraire good $y$ simplifies the analysis.

The budget constraint of the representative agent in country $j$ is

$$
y_{j}^{0}+w_{j} L_{j}+\sum_{i=N, S} \int_{\omega_{j} \in \Omega_{j}} \Pi_{i}\left(\omega_{j}\right)=y_{j}+p_{C j} C_{j}+\sum_{i=N, S} \int_{\omega_{i} \in \Omega_{i}} p_{j}\left(\omega_{i}\right) f_{j}\left(\omega_{i}\right),
$$

where $y_{j}^{0}$ is the endowment of the numeraire in country $j, \Pi_{i}\left(\omega_{j}\right)$ is the profit from sales of variety $\omega_{j}$ to country $i, y_{j}$ is the amount of the numeraire consumed in country $j, p_{C j}$ is the price of the catalyst in $j$, and $p_{j}\left(\omega_{i}\right)$ is the price of variety $\omega_{i}$ in $j$.

Consumer optimization with respect to $f_{j}\left(\omega_{i}\right)$ yields demand for variety $\omega_{i}$ in country $j$ :

$$
f_{j}^{d}\left(\omega_{i}\right)=\frac{1}{\gamma}\left(C_{j}^{\alpha}-p_{j}\left(\omega_{i}\right)\right)
$$

Similarly, the first order condition with respect to $C_{j}$ yields

$$
C_{j}^{d}=\left(\frac{\alpha F_{j}}{p_{C j}}\right)^{\frac{1}{1-\alpha}},
$$

where $F_{j} \equiv \sum_{i=N, S} \int_{\omega_{i} \in \Omega_{i}} f_{j}\left(\omega_{i}\right)$ is the total quantity of final goods consumed in country $j$.

Consumption Good Sector. Output in the final goods sector is produced using the technology

$$
f\left(\omega_{j}\right)=A_{j} L_{\omega_{j}}
$$

where $f\left(\omega_{j}\right) \equiv f_{N}\left(\omega_{j}\right)+f_{S}\left(\omega_{j}\right)$. Each firm $\omega_{j}$ charges a country-specific price to maximize the profits $\Pi_{i}\left(\omega_{j}\right)$ from selling variety $\omega_{j}$ in country $i \in\{N, S\}$. I assume that if 
$p_{S}\left(\omega_{S}\right) \neq p_{N}\left(\omega_{S}\right)$, the costs to consumers in country $\left\{j: p_{i}\left(\omega_{S}\right)<p_{j}\left(\omega_{S}\right)\right\}$ of purchasing good $\omega_{S}$ in $i$ are sufficiently high to prevent arbitrage. Likewise, costs to consumers of transporting good $\omega_{N}$ across international borders are sufficiently high to prevent arbitrage when $p_{S}\left(\omega_{N}\right) \neq$ $p_{N}\left(\omega_{N}\right)$.

Profits from sales of $\omega_{j}$ in $i$ can be written

$$
\Pi_{i}\left(\omega_{j}\right)=p_{i}\left(\omega_{j}\right) f_{i}\left(\omega_{j}\right)-\frac{w_{j}}{A_{j}} f_{i}\left(\omega_{j}\right)
$$

The profit-maximizing price charged in country $i$ is

$$
p_{i}\left(\omega_{j}\right)=\frac{1}{2}\left(C_{i}^{\alpha}+\frac{w_{j}}{A_{j}}\right) .
$$

Equation (20) states that the optimal price of an identical good varies across countries based on the stock of catalyst goods in each country. This is the key result of the paper, and it explains why rich countries pay higher prices for tradable goods. Of course, it remains to be seen that rich countries have more of the catalyst in equilibrium, a task to which we now turn.

Given the price defined by (20), consumer demand in country $i$ for $\omega_{j}$ is

$$
f_{i}^{d}\left(\omega_{j}\right)=\frac{1}{2 \gamma}\left(C_{i}^{\alpha}-\frac{w_{j}}{A_{j}}\right),
$$

The resulting revenues of firm $\omega_{j}$ from sales to country $i$ are

$$
p_{i}\left(\omega_{j}\right) f_{i}\left(\omega_{j}\right)=\frac{1}{4 \gamma}\left(C_{i}^{2 \alpha}-\frac{w_{j}^{2}}{A_{j}^{2}}\right),
$$

and profits are

$$
\Pi_{i}\left(\omega_{j}\right)=\frac{1}{4 \gamma}\left(C_{i}^{\alpha}-\frac{w_{j}}{A_{j}}\right)^{2} .
$$

Catalyst Sector. As in Section 2, the catalyst in country $j$ is produced competitively according to $C_{j}=A_{j} L_{C j}$, where $A_{j}$ is productivity in country $j$ and $L_{C j}$ is labor employed in $j$ 's catalyst sector. The price of the catalyst is $p_{C j}=w_{j} / A_{j}$, which is derived from cost minimization by the representative catalyst firm. Since the catalyst is not traded across countries, there is no role for comparative advantage and each country will produce some of the catalyst in equilibrium.

Equilibrium. Since $p_{i}\left(\omega_{j}\right)$ and $f_{i}\left(\omega_{j}\right)$ are identical for any variety $\omega_{j}$ from country $j$, it will be helpful to omit variety indices by writing $p_{i j}=p_{i}\left(\omega_{j}\right), f_{i j}=f_{i}\left(\omega_{j}\right)$, and $\Pi_{i j}=$ 
$\Pi_{i}\left(\omega_{j}\right) \forall \omega_{j} \in \Omega_{j}$. Then $F_{j}$ becomes $F_{j}=\Omega_{j} f_{j j}+\Omega_{i} f_{j i}$. The budget constraint in country $j$ simplifies to

$$
y_{j}^{0}+w_{j} L_{j}+\Omega_{j}\left(\Pi_{j j}+\Pi_{i j}\right)=y_{j}+p_{C j} C_{j}+\Omega_{j} p_{j j} f_{j j}+\Omega_{i} p_{j i} f_{j i}
$$

Labor market clearing in $j$ is $L_{j}=L_{Q j}+L_{C j}$, where $L_{Q j} \equiv \int_{\omega_{j} \in \Omega_{j}} L_{\omega_{j}} d \omega_{j}$ is total labor used in the final goods sector. By substituting in the production functions for final goods and the catalyst, labor market clearing in country $j$ can be written

$$
L_{j}=\frac{1}{A_{j}}\left(\Omega_{j}\left(f_{j j}+f_{i j}\right)+C_{j}\right) .
$$

Market clearing for the numeraire is

$$
y_{N}^{0}+y_{S}^{0}=y_{N}+y_{S} .
$$

Equilibrium is characterized by demand for the catalyst in each country (17), demand for final goods (21), labor market clearing in each country (25), market clearing for the numeraire (26), and the budget constraints (24). By Walras' Law, one of these equations is redundant. For clarity, the equilibrium conditions are written explicitly as:

$$
\begin{gathered}
C_{N}=\left(\frac{A_{N} \alpha\left(\Omega_{N} f_{N N}+\Omega_{S} f_{N S}\right)}{w_{N}}\right)^{\frac{1}{1-\alpha}}, \quad C_{S}=\left(\frac{A_{S} \alpha\left(\Omega_{N} f_{S N}+\Omega_{S} f_{S S}\right)}{w_{S}}\right)^{\frac{1}{1-\alpha}}, \\
f_{N N}=\frac{1}{2 \gamma}\left(C_{N}^{\alpha}-\frac{w_{N}}{A_{N}}\right), \quad f_{N S}=\frac{1}{2 \gamma}\left(C_{N}^{\alpha}-\frac{w_{S}}{A_{S}}\right), \\
f_{S S}=\frac{1}{2 \gamma}\left(C_{S}^{\alpha}-\frac{w_{S}}{A_{S}}\right), \quad f_{S N}=\frac{1}{2 \gamma}\left(C_{S}^{\alpha}-\frac{w_{N}}{A_{N}}\right), \\
L_{N}=\frac{1}{A_{N}}\left[\Omega_{N}\left(f_{N N}+f_{S N}\right)+C_{N}\right], \quad L_{S}=\frac{1}{A_{S}}\left[\Omega_{S}\left(f_{S S}+f_{N S}\right)+C_{S}\right], \\
y_{N}^{0}+y_{S}^{0}=y_{N}+y_{S}, \\
y_{N}^{0}-y_{N}+\Omega_{N} p_{S N} f_{S N}=\Omega_{S} p_{N S} f_{N S},
\end{gathered}
$$

where the last equilibrium equation is a simplified version of the budget constraint for country $N$ (see equation 24). The ten equations above yield a unique solution for the endogenous variables $w_{N}, w_{S}, y_{N}, y_{S}, C_{N}, C_{S}, f_{N N}, f_{N S}, f_{S S}$, and $f_{S N}$.

Results. Figure 2 shows relative prices in $N$ and $S$ of identical goods under the following baseline parameterization: 


$$
A_{N}, A_{S}=3, \quad L_{N}, L_{S}, y_{N}^{0}, y_{S}^{0}=1, \quad \Omega_{S}, \Omega_{N}=0.5, \quad \alpha, \gamma=0.3^{7}
$$

The left-hand graph shows the ratio of prices relative to the numeraire, while the graph on the right shows the ratio of PPP-adjusted prices. ${ }^{8}$ According to Figure 2, the model predicts that as a country gets richer, it pays higher prices for identical goods than does its poorer counterpart, consistent with the evidence across countries cited in the introduction. Specifically, goods produced in $N$ are more expensive in $N$, and goods produced in $S$ are more expensive in $N$.

Figure 3 shows how market outcomes vary with productivity in $N$. As $A_{N}$ rises, $N$ produces and consumes more of the catalyst. Higher catalyst consumption shifts out the demand curves of final goods, which causes firms from both countries to charge higher markups for goods sold in $N$. The resulting quantities of final goods demanded by $N$ increase because the outward shift of the demand curves caused by higher catalyst consumption outweighs the movement along the demand curves caused by higher prices. Therefore a rise in $A_{N}$ causes higher catalyst and final good consumption in $N$, as well as higher prices of final goods.

The rise in $f_{N S}$ requires $S$ to devote more labor resources to its export sector and less resources to production for domestic consumption, causing a fall in $f_{S S}$ and $C_{S}$. How is this optimal for $S$ ? Since exports from $S$ are sold at a higher markup, the value of exports $f_{N S}$ increase relative to the value of the numeraire. $S$ therefore reallocates labor to the export sector to exchange for the numeraire and for consumer goods produced in $N$, leading to an increase in trade and an increase in welfare in $S$. Figure 4 shows that welfare in both countries increases with $A_{N}$.

Summary of the Two-Country Model. As productivity in $N$ increases, $N$ can afford to produce more catalyst goods, which shifts out its demand for final goods by increasing the price-

\footnotetext{
${ }^{7}$ Baseline productivity is set to 3 to ensure that utility from consumption of final goods and catalyst goods is sufficiently high to ensure positive demand for imports from $N$ and $S$. In other words, the productivity parameters are chosen such that the equilibrium is at an interior solution given by the ten equilibrium equations above. ${ }^{8}$ In Figure $4, p_{i j}^{R} \equiv p_{i j} / P_{i}$, where $P_{i}$ is the consumer price index. $P_{i}$ is normalized to unity under the initial calibration in which productivity is equal across countries. Note that PPP holds when $N$ and $S$ are equal because the exact same bundles are purchased at identical costs in each country. When productivity is not equal across countries (e.g. at any point in Figure 4 to the right of the y-axis), $P_{i}$ is the current price in country $i$ of the bundle of goods consumed when PPP held (the Laspeyres Index):

$$
P_{i}=\frac{y_{i}^{0}+p_{C i} C_{i}^{0}+p_{i j} \Omega_{j} f_{i j}^{0}+p_{i i} \Omega_{i} f_{i i}^{0}}{y_{i}^{0}+p_{C i}^{0} C_{i}^{0}+p_{i j}^{0} \Omega_{j} f_{i j}^{0}+p_{i i}^{0} \Omega_{i} f_{i i}^{0}},
$$

where the superscript 0 indicates the price or quantity that prevails when PPP holds (productivity is equal across countries).
} 
intercept of the demand curve. $N$ 's resulting lower price elasticity of demand causes firms to charge a higher markup in $N$ than in $S$, which increases relative prices in $N$.

As we will see in Section 4 below, this simple explanation of demand complementarity and pricing-to-market can explain not only high prices of traded consumer goods in rich countries, but also high prices of nontradables in rich countries.

\section{Incorporating Nontradable Goods and Services}

This section extends the analysis of Section 3 to demonstrate that the mechanism emphasized above to account for the comparatively high prices of tradables in rich countries can also account for the comparatively high prices of nontradables in rich countries. ${ }^{9}$ The typical explanation for the observed correlation between country income per capita and nontradable prices is based on the theory developed by Harrod (1933), Balassa (1964), and Samuelson (1964). The HBS model assumes that the law of one price (LOP) holds in tradables, and that rich-country productivity is higher in the tradable sector than in the nontradable sector. High productivity in the tradable sector drives up wages in rich countries, which causes higher prices in the sector with lower productivity (nontradables).

As recently noted by Alessandria and Kaboski (2011), the rise in relative productivity of tradables within rich countries appears too small to account for the strong relationship between prices and incomes across countries. Their evidence suggests that differences in prices of services across countries cannot be solely attributed to differences is costs; and that markups for nontradables are higher in countries with high per capita income.

This section offers a new explanation to account for comparatively high prices of nontradables in Rich countries based on complementarity between catalyst goods and final goods, as in Section 3. Rich countries can afford to produce more catalyst goods, which in turn increases demand for nontradable goods and services.

Consider, for example, purchasing car rental services in Ecuador, which has unpaved roads and a generally unsafe environment for driving. Even if a car rental agency can provide a vehicle to rent at low cost, customers will have low preference for this service simply because there are characteristics specific to Ecuador (poor driving conditions) which may not affect the

\footnotetext{
${ }^{9}$ This high price of nontradables in rich countries is well-documented. See, for example, Alessandria and Kaboski (2011, p.92).
} 
cost to the firm of providing the service, but which reduce customers' utility from the service. Likewise, the utility from a haircut may depend on the prevalence of other goods and services for which one might need a haircut to fully enjoy. Salon services are more valuable, for example, when consumers attend formal events in which a certain style of appearance is the cultural norm. Notice that in this last example, the complementary catalyst is itself a service.

Utility from nontradable services also depends on durables, such as housing. For example, the value of services such as window-washing, carpet-cleaning, and lawn mowing all depend on whether consumers have homes that can accommodate windows, carpets, and lawns. In Quito, Ecuador, these services are of little value because few homes there are suitable for windows and nice carpets, and few households own lawns.

The model that formally demonstrates the dependence of prices of nontradables on catalyst consumption is a straightforward extension of the model in Section 3. I therefore omit the details of the model, which are available from the author upon request. Figure 5 shows market outcomes in the model as productivity in $N$ increases, where $f_{j}$ refers to consumption of any nontradable service in country $j \in\{N, S\}$ and $p_{j}$ refers to the price of any nontradable service in country $j$. The results are very similar to those from Section 3: N's production and consumption of catalyst and final goods increases, as does the price of tradables in $N$. In addition, the relative price of services is higher in $N$ because the increase in $C_{N}$ lowers the price elasticity of demand for services, causing service-sector firms in $N$ to charge a higher markup than service-sector firms in $S$.

Summary of Two-Country Model with Services. The value of services within a country rises with that country's stock of catalyst goods. A rich country can afford to produce more of the catalyst, which lowers the price elasticity of demand for tradable final goods and nontradable services within the country. As a result, monopolistically competitive firms in the final good and service sectors charge a higher markup, causing higher prices of tradable goods and nontradable services in the rich country.

\section{Empirical Evidence}

So far I have emphasized the ability of a demand complementarity and pricing-to-market to theoretically account for high prices of goods and services in countries with high per-capita incomes. Here I test the dependence of consumer prices on countries' consumption of catalyst 
goods using data on U.S. and Chinese exports. The challenge in the empirical work is to distinguish the effect of demand complementarities from other mechanisms that may cause a positive correlation between consumer prices and income per capita across countries. Indeed, income and catalyst consumption are perfectly correlated in the theoretical models above, and if the same were true of reality it would be impossible to distinguish between demand complementarities and other potential explanations for the price-income relationship. In reality, however, catalyst consumption is imperfectly correlated with income per capita, which permits me to test the dependence of prices on the component of catalyst consumption that is not correlated with income. ${ }^{10}$

The analysis in this section examines three catalyst goods in particular: electricity, housing, and roads. Each of these catalyst goods is an imperfect correlate with GDP per capita, and each is expected to be a strong complement for a different subset of consumer goods. Electricity complements demand for electric goods, houses complement demand for household goods (e.g. televisions and furniture), and roads complement demand for new cars. Therefore, the model predicts the following, conditional on country-level fixed effects:

1) Electric goods are sold at higher prices in countries with a more reliable power supply (or superior energy infrastructure).

2) Household goods are sold at higher prices in countries with more housing per capita.

3) New cars are more expensive in countries with better roads.

To explore these predictions, I obtain prices of goods sold to different countries from disaggregated data on U.S. and Chinese exports. The U.S. Exports Harmonized System data, available on Robert Feenstra's webpage, contains unit values and quantities of bilateral exports leaving US docks for each Harmonized System (HS)-10 product category. As discussed by Alessandria and Kaboski (2011), there are two advantages of using this data to study the extent of pricing-to-market for tradable goods. First, the unit values are free-alongside-ship values, which exclude transportation costs, tariffs, and additional costs incurred in the importing country. Thus the unit values capture the actual price of the good, rather than the price of taking

\footnotetext{
${ }^{10}$ There are many potential reasons for the imperfect correlation between catalyst consumption and income. I do not suggest any particular reason, but assume that these reasons are exogenous to prices of consumer imports. In the models above, it is straightforward to introduce imperfect correlation between catalyst consumption and income by assuming that productivity in the catalyst sector has a random component.
} 
the good to retail. Second, the disaggregated nature of the data mitigates potential concerns that different unit values may reflect differences in quality. ${ }^{11}$

To test the three hypotheses it is necessary to identify 'household goods', 'electric goods', and 'new cars' separately from other consumer goods. This task is fairly straightforward for new cars, which I classify as any good for which its HS-10 description indicates that it is a new passenger vehicle. Identification of electric goods is also fairly straightforward, although some goods are not identified as electric but require electricity to use (such as a television). I classify as 'electric' any consumer good (end-use code 40000-50000) that is labeled as electric and not battery-powered, as well as a number of clearly electric goods, including TVs, stereos, and associated parts.

Classifying household goods is more difficult because most consumer goods are stored in homes. Nonetheless, some goods are more directly complementary to housing than others. Consider a house with an extra bedroom and bathroom. The extra space is likely to complement demand for furniture, bedding, towels, and similar goods. Also, a country with more homes per capita will have more need for kitchen items. Therefore I classify all furniture, glassware, chinaware, cookware, cutlery, tools, rugs, TVs, VCRs, and stereo equipment (end-use codes 41000, 41010, 41020, 41040, 41200, and 41210) as household goods. I also classify appliances (end-use 14030) as household goods, with the exception of air conditioners and radiators, the demand for which I assume depends more on weather than on housing. Other goods such as clothing and personal care items are excluded from the list of household goods because they are not directly complementary to housing. Table 1 lists the subset of consumer goods that I classify as household goods.

To corroborate the evidence from U.S. export data, I test hypotheses 1 and 2 using Chinese Customs export data, which contain free-alongside-ship values and quantities of goods at the HS-8 level of disaggregation. ${ }^{12}$ Despite the lower level of disaggregation, the Chinese dataset has a number of advantages over the U.S. export data. First, the dataset contains identifiers for firms and firm locations, which help control for quality variation within a product

\footnotetext{
${ }^{11}$ Despite the disaggregated nature of the data, there is still room for quality variation within a product category. Therefore, as discussed below, I take a number of steps to help condition on quality, such as normalizing prices by their with-product standard deviation and dropping goods with long quality ladders from the sample.

${ }^{12}$ I am incredibly grateful to Jagadeesh Sivadasan and Michael Olabisi for sharing the Chinese Export data. I do not test the third hypothesis using the Chinese data because the dataset does not include and exports of new passenger vehicles in 2005 .
} 
category. Second, China exports far more consumer goods to a broader range of countries. The Chinese dataset does not have end use codes or descriptions, so I identify consumer, household, and electronic good HS-8 categories as those categories that contain only consumer goods, only household goods, and only electronic goods as HS-10 subcategories.

Country-level data on the catalyst goods are from the International Comparison Program (ICP) and the World Development Indicators at the World Bank. Heston (2011) provides the ICP's measures of the dwelling services for Europe in 2005. The measure of the dwelling services in Europe is based on a survey of rental rates, from which the ICP assigned countries an index of their per capita housing volume. Measures of housing volume in other regions are either unreliable, or are not comparable to the measure of housing in Europe (see Heston 2011 for a discussion).

I use electricity consumption as a proxy for a country's energy infrastructure. Countrylevel data on electricity consumption per capita are from the World Development Indicators at the World Bank. The measure of a country's road quality is the percent of roads that are paved, also available from the World Development Indicators. Most countries do not have data on road quality for more than a single year between 2002 through 2006, so I pick the most recent year for which data is available as a country's measure of road quality.

I test the three hypotheses outlined earlier separately in the following subsections.

\subsection{Electricity Infrastructure and Prices of Electric Goods}

First, I assess whether prices of exports of electric goods depend on countries' access to electricity. As a proxy for a country's electricity access, I use data on electricity consumption per capita, provided by the World Development Indicators. This proxy is most appropriate in underdeveloped countries with low average electricity consumption per capita. In developed countries, differences in electricity consumption are more likely to reflect differences in factors other than the population's access to electricity, such as weather. Therefore I limit my attention to countries that consumed less than 5 mega-watt-hours of electricity per person in 2005 . This restriction removes most European countries from the sample, as well as other wealthy countries such as Japan and Qatar, and leaves 72 countries in the sample. Portugal, South Africa, and Malta are the remaining countries with the highest per capita electricity consumption.

I test the following empirical specification: 


$$
p_{c h}=\alpha_{c}+\gamma_{h}+\psi q_{c h}+\beta \text { MWHpercap } \operatorname{Egood}_{h}+\epsilon_{c h}
$$

where $p_{c h}$ is the $\log$ of the unit value of good $h$ exported to country $c$, normalized by its withingood standard deviation. ${ }^{13}$ The coefficient $\alpha_{c}$ represents country fixed effects, $\gamma_{h}$ represents fixed effects for each good category, and $q_{c h}$ is the $\log$ quantity of good $h$ sold to country $c$, normalized by its within-good standard deviation. MWHpercap ${ }_{c}$ is the per capita electricity consumption in country $c$, Egood $_{\mathrm{h}}$ indicates whether good $h$ is electric, and $\epsilon_{c h}$ denotes the regression error. Unit values and quantities for each country-product pair in the U.S. data are averages of the values between 2004 and 2006 (the three most recent years available). ${ }^{14}$ The Chinese data are only available in 2005 . To prevent nonrepresentative products from driving the results, the samples are limited to country-product pairs with over 100 units sold and to products that are exported to at least 10 countries.

The coefficient $\beta$ captures the extent to which the markup for electric goods depends on electricity access. $\beta$ can be interpreted as representing a causal relationship if electricity consumption is exogenous to the product price. Electricity consumption is indeed likely to be exogenous with respect to the price of a single imported product. If there is any endogenous response to electric prices, equations (16) and (17) imply electricity consumption should respond negatively to high import prices. In this case, high electricity consumption is associated with low prices of electric goods, and $\beta$ will underestimate the causal effect of access to electricity on electric goods prices. In other words, the estimate of $\beta$ is biased downward in the presence of endogenous electricity consumption. ${ }^{15}$

I include quantity as a regressor in (27) to capture the dependence of firms' costs on the quantity they sell to a given destination. A negative estimate for $\psi$ may reflect bulk discounts, or other cost savings from repeated transactions between U.S. sellers and foreign buyers. Omitting

\footnotetext{
${ }^{13}$ When the regression is run on Chinese data, the price is normalized by its standard deviation within a firmproduct pair. This normalization prevents goods with large price dispersion from driving the results, and mitigates potential concerns that the regression results may be driven by differences in quality. Manova and Zhang (2012), for example, document that Chinese firms that charge a wide range of prices for their exports also pay a wide range of prices for imported inputs. They infer on the basis of this evidence that these firms sell goods of varying quality.

${ }^{14}$ Averaging unit values across time has the advantage of averaging out the noise in the yearly data while preserving the ability to identify $\beta$ based on the cross-sectional variation across destination countries. When the regression is run on yearly data (rather than averaged data), the results are similar but with slightly larger standard errors.

${ }^{15}$ As a robustness check, I used 2002 values of electricity consumption as an instrument and obtained nearly identical results to those presented below. This is unsurprising given that electricity consumption in 2005 is nearly perfectly correlated with electricity consumption in prior years.
} 
quantity would bias downward $\beta$ to the extent that higher electricity-related demand for electric goods is associated with higher quantities sold and lower marginal costs.

More generally, conditioning on quantity controls for demand parameters and cost parameters that may vary across country-product pairs. Monopolistically competitive firms charge a price that depends on catalyst consumption as well as other demand and cost parameters. Since these parameters may vary across countries in a way that is correlated with catalyst consumption, conditioning on quantity controls for these parameters and permits an interpretation of $\beta$ as the partial effect on the price of an increase in catalyst consumption, conditional on a country's position on its demand curve. ${ }^{16}$

Table 2 shows the estimates from the U.S. export data. According to column (1), a megawatt-hour increase in per capita electricity consumption is associated with a $6.0 \%$ increase in the price of electric goods, where a megawatt-hour is approximately the difference in per capita electricity consumption between Zimbabwe and Turkey. This estimate is statistically significant at the $1 \%$ level of significance.

A typical concern in empirical work studying the determinants of export prices is that high prices reflect higher-quality goods. While the disaggregate nature of the data and the normalization of prices by their within-good standard deviation mitigate this concern to some extent, there may still remain scope for quality variation within an HS-10 category. To address this concern, Subsample 2 in Table 2 drops from the sample all electric goods with long quality ladders. Specifically, I use the quality ladder estimates from Khandelwal (2010), and I drop all electric goods with ladder estimates above the median estimate. ${ }^{17}$ The sample retains other consumer goods with long ladder estimates. Therefore, the regression will, if anything, understate the dependence of prices of electric goods on electricity access. This is because, to the extent that high export prices reflect high quality consumer goods sold to rich countries, the regression will estimate a high value of the country fixed effect for rich countries. Since electricity consumption is positively correlated with per capita income, some of the dependence

\footnotetext{
${ }^{16}$ The qualitative results below are generally robust to omitting quantity from the regression.

${ }^{17}$ Approximately half of the HS-10 categories have nonmissing ladder estimates. Those with missing ladder estimates are kept in the sample. Note that long quality ladder estimates for a final good may reflect strong complementarity with catalyst goods, rather than high quality. This is because the estimates of ladder length in Khandelwal (2010) are based on the assumption that high market share (conditional on price) reflects high quality. In the models above, goods with high degrees of complementarity also have high market share. Thus dropping goods with long estimated quality ladders may remove some goods that are strong complements with catalyst goods, thus biasing downward the estimated relationship between catalysts and the prices of final goods.
} 
of prices on housing will be captured by the high fixed effect estimates in rich countries. The estimates in column (2) are similar to those in column (1), suggesting that the results are driven by pricing-to-market rather than by quality differences.

The results in columns (1) and (2) of Table 2 strongly support the hypothesis that prices of electric goods across countries depend on electricity access. However, the correlation between GDP per capita and MwH per capita for the sample of destination countries is 0.75 and the possibility remains that the estimate of $\beta$ captures the dependence of prices of electric goods on a component of income that is not fully captured by the country level fixed effects. In other words, it is possible that electric good prices have an above average dependence on income per capita, and that the estimate of $\beta$ is capturing this dependence. To verify that this positive estimate of $\beta$ is driven by electricity access as a catalyst, rather than by other mechanisms associated with high incomes, column (3) reports the results from a modified version of specification (27) in which electricity consumption is interacted with log GDP per capita:

$$
p_{c h}=\alpha_{c}+\gamma_{h}+\psi q_{c h}+\beta \text { MWHpercap }_{c} \operatorname{Egood}_{h}+\beta_{2} \operatorname{GDPpercap}_{c} \operatorname{Egood}_{h}+\epsilon_{c h}
$$

$\beta_{2}$ captures the extent to which electric goods are associated with high incomes per capita, conditional on country-specific determinants of consumer goods prices and conditional on the dependence of prices of electric goods on electricity access. According to column (3), the estimate of $\beta_{2}$ is not significantly different from zero, while the new estimate of $\beta$ is lower and less significant. These results suggest that specification (28) lacks the power to distinguish the relative importance of electricity consumption per capita and income on the prices of electric goods. As we will see, the empirical test using Chinese export data is more powerful and indicates that there is a statistically and economically significant dependence of prices of electric goods on electricity access, even when conditioning on income per capita.

The results from the Chinese export data are qualitatively similar to the results from U.S. export data. Table 3 shows that a $\mathrm{MwH}$ per capita increase in electricity consumption is associated with a statistically significant $2 \%$ to $3 \%$ increase in prices of electric goods. To the extent that the product-firm-firm $\times$ location dummies effectively condition on quality, the positive estimate of $\beta$ from the Chinese data can be interpreted as evidence of pricing-to-market. Column (2) of Table 3 shows that the estimate of $\beta_{2}$ is negative and insignificant, while the estimate of $\beta$ is large and strongly significant. This suggests that any dependence of electric 
good prices on income is similar to the dependence of consumer goods prices on income as captured by the country-level fixed effects. Thus, the U.S. and Chinese export data appear to support the hypothesis that electricity access is a catalyst for demand for electric goods, and that electric goods are more expensive in countries with superior access to electricity. ${ }^{18}$

\subsection{Housing Volume and Prices of Household Goods}

Next, I assess whether prices of exports of households goods depend on European countries' stock of housing. Europe is an especially suitable region for such an investigation because its countries have low levels of within-country inequality, mitigating potential concerns that housing volume of the average resident may differ from housing volume of the consumer driving demand for household goods. Furthermore, housing volume is generally high in Europe, so a marginal increase in volume, such as an additional room, is likely to increase demand for furnishings of those rooms. ${ }^{19}$

The empirical specification is

$$
p_{c h}=\alpha_{c}+\gamma_{h}+\psi q_{c h}+\beta \operatorname{Vol}_{c} \operatorname{HHgood}_{h}+\epsilon_{c h}
$$

where $\mathrm{Vol}_{\mathrm{c}}$ is the measure of the housing stock in country $c, \mathrm{HHgood}_{\mathrm{h}}$ indicates whether the good is classified as a household good, and $\epsilon_{c h}$ denotes the regression error. The remaining variables are defined as above. All data are 2005 values, the only year for which data on Europe's housing stock is available. The baseline sample excludes all HS-10 products sold to less than 10 countries, and all product-country pairs for which less than 100 units were sold.

The coefficient $\beta$ captures the extent to which the markup for household goods depends on housing volume. According to Column 1 in Table 4, a standard deviation increase in a European country's housing volume index is associated with a $5.7 \%$ increase in the price of household goods. This estimate is significant at the $1 \%$ level of significance and is robust to dropping household goods with long quality ladders from the sample (column 2). This suggests that the estimated relationship between prices of household goods and a country's housing stock

\footnotetext{
${ }^{18}$ Falsification exercises verify that other subsets of consumer goods (e.g. clothing, battery-powered goods, luxury goods, etc) do not have an above-average dependence on electricity consumption, which suggests that the positive dependence of electric goods prices on electricity consumption is indeed due to demand complementarity.

${ }^{19}$ In less developed regions, differences in volume are less likely to translate into marginal increases in demand for household goods; rather, in less developed countries, higher volume may imply an increase in personal space but not an increase in demand for furnishing.
} 
does not reflect high quality consumer goods being sold to countries with high housing volumes. Rather, the relationship reflects primarily a failure of the law of one price for household goods such that identical household goods are more expensive in countries with more housing per capita.

Column 3 shows the results from a modified version of equation (29) in which the interaction between log GDP per capita and an indicator for household goods is included as a regressor:

$$
p_{c h}=\alpha_{c}+\gamma_{h}+\psi q_{c h}+\beta \operatorname{Vol}_{c} \operatorname{HHgood}_{h}+\beta_{2} \operatorname{GDPpercap}_{c} \operatorname{HHgood}_{h}+\epsilon_{c h}
$$

The estimate of $\beta_{2}$ is not significantly different from zero, and the estimate of $\beta$ remains large and significant, suggesting that housing is a catalyst that is associated with high prices of household goods and that the dependence of household goods prices on income is captured by the country-level fixed effects.

To determine which goods are driving this strong relationship, I reclassify goods into subcategories of household goods (e.g. dishwashers, kitchen appliances, etc.), and rerun the Subsample 2 regression by interacting housing volume with each subcategory. Televisionrelated goods (e.g. antennas and satellite dishes) and refrigerators are the most important contributors to the observed relationship between a country's housing stock and the price it pays for household goods, followed closely by household furnishings. This result does not imply that housing does not complement demand for other household goods; rather, it is a reflection of the relatively high quantity of U.S. exports of television and refrigerator-related goods. Housing may complement demand for dishwashers, but U.S. exports of dishwashers to Europe are insufficient to provide a precise estimate of this relationship.

The results from specification (29) on Chinese export data correspond to those from the U.S. data. According to Column 1 in Table 5, a standard deviation increase in housing volume is associated with a $1.6 \%$ increase in the prices of Chinese exports of household goods. However, the dependence of household goods prices on housing disappears under regression (30) in which GDPpercap $_{c} \mathrm{HHgood}_{h}$ is included as a regressor. This may be due to the high correlation between GDP and housing across European countries in the sample (0.9), or it may be a consequence of the way in which housing volume is calculated. The ICP's measure of housing volume includes the service flow from the quality of the house (age of the house, heating quality, 
etc). If housing volume is more important than housing quality for demand for household goods, then the ICP measure will misrepresent the amount of housing catalyst across countries.

The ICP provides an alternative measure of housing volume based on the Consumption Equivalent Method (CEM), which assumes that housing volume is proportional to private consumption expenditures. The reader is referred to Heston (2011) for a more detailed comparison of the two measures. The two measures are very different for some countries, reflecting in part differences in the different weights placed on housing quality. Columns (3) and (4) of Table 5 show that the dependence of prices of household goods on the CEM measure of housing volume is much higher than is predicted by the baseline measure.

Which housing measure is a more accurate measure of housing as a catalyst? One way to distinguish between the two measures is to see which predicts a higher dependence of prices of luxury goods on income per capita. Luxury goods are assumed to have an above-average dependence on income per capita, and an ambiguous (but likely average) dependence on housing. I identify luxury goods as those related to water sports, tennis, golf, skiing, and adventure sports. According to Columns (5) and (6), the baseline housing measure predicts an above-average dependence of luxury prices on housing, while the CEM measure predicts an above-average dependence of luxury prices on income per capita. By this criterion, therefore, it appears that the alternative CEM housing measure is the more accurate measure of housing volume, and that prices of household goods have an above-average dependence on housing volume.

Using the CEM measure in place of the baseline volume measure on the U.S. data is less conclusive. The coefficients on the CEM measure and on GDP per capita are both positive but statistically insignificant (not shown). The dependence of luxury goods prices on the CEM measure is negative but insignificant. Thus it's not clear that the CEM measure more accurately captures the aspect of housing that is the relevant catalyst for household goods produced in the U.S.

It is possible that the CEM measure, which may be a better measure of volume, more accurately captures the catalyst for Chinese-produced household goods, while the baseline measure, which is perhaps a better measure of quality, more accurately captures the catalyst for U.S.-produced household goods. This would be the case if, for example, housing quality is a 
catalyst for higher-quality household goods, and the U.S. produces higher-quality household goods than does China.

\subsection{Paved Roads and Prices of New Cars}

Data on the percent of paved roads are available across regions for different years between 2003 and 2006. I take the most recent year for which data are available in a country as that country's measure of road quality and estimate the following specification:

$$
p_{c h}=\alpha_{c}+\gamma_{h}+\psi q_{c h}+\beta \operatorname{Road}_{\mathrm{c}} \operatorname{Newcar}_{\mathrm{h}}+\epsilon_{c h}
$$

where $\operatorname{Road}_{\mathrm{c}}$ is the percent of roads that are paved in country $c$ and Newcar indicates whether good $h$ is a new car. The remaining variables are defined as above. Specification (31) is tested only on U.S. data since the Chinese Customs data do not include sales of new cars in 2005. Unit values and quantities for each country-product pair are averages of the values between 2004 and 2006 (the three most recent years of data). The sample excludes all HS-10 products sold to less than 10 countries, and all product-country pairs for which less than $\$ 10,000$ worth of goods were sold. $^{20}$

Table 6 shows the results from specification (31). In columns (1) and (2), the sample includes all exported non-military goods (end use classification 0 through 4 ). Column (1) states that a percentage point increase in the fraction of roads that are paved is associated with a 0.6 percent increase in the price of new cars. This relationship is statistically significant. While prices of new cars depend on road quality, column (2) suggests that the paved roads are not associated with high prices of other automobiles or auto parts. To corroborate the evidence in column (2), columns (3) and (4) restrict the sample to auto-related exports so that country-level fixed effects are determined by the relationship of prices of auto-related goods across countries. Consistent with the evidence in regression (1), regressions (3) and (4) show that road quality is associated with high prices of new cars, even conditional on country-level determinants of prices of auto-related goods. The relationship between road quality and prices of new cars is statistically significant and is robust to the inclusion of log GDP per capita interacted with an

\footnotetext{
${ }^{20}$ The sample does not restrict observations based on the quantity of goods because cars are assumed to be sold in lower quantities on average than are consumer goods. Indeed, using the same cutoff threshold of 100 units in Sections 5.1 and 5.2 would remove almost two-thirds of the new car observations from the sample.
} 
indicator variable for new cars as a regressor, suggesting that road quality is associated with high prices of new cars conditional on any price association due to destination-country income. ${ }^{21}$

The evidence in Table 6 suggests that road quality complements demand for new cars but not demand for automobiles generally and auto parts. One possible explanation for this result is that demand for automobiles (used or new) is driven primarily by the need for transportation, regardless of the quality of the roads. Demand for new cars relative to used cars, however, depends on the enjoyment of driving, in addition to efficient travel. A new Cadillac is not much more effective than an old jeep at transporting an individual over a mile of dirt road. However, a luxury Cadillac may be more effective at transporting someone on paved roads, and it is likely to be a more comfortable experience.

An additional explanation for the insignificant relationship between auto parts in general and paved roads is that demand for auto parts may be high when roads are in poor condition. Not only are consumers less likely to purchase new cars (for which new parts are not immediately necessary) when roads are poor, but bad roads cause car damage and thus necessitate constant repair and frequent need for replacement parts.

The general message from Table 6 is consistent with the model's predictions based on demand complementarity and pricing-to-market: road quality is associated with higher prices of new cars. The main caveat is that the results may simply reflect the fact that higher quality cars are sold to countries with higher quality roads. Since new cars have long quality ladders, this concern cannot be addressed as in Sections 5.1 and 5.2 by dropping products with short quality ladders.

In reality, high prices of new cars are likely a result of both sales of high-quality cars and pricing to market for identical models. The standard assumption in the literature has been that price differences reflect quality differences, but recent evidence has demonstrated a strong role for price discrimination across countries for a range of products. ${ }^{22}$ Thus it seems reasonable to infer price discrimination in the auto market as well. Precisely identifying the relative importance of pricing-to-market in the auto industry will require price data on identical models.

\footnotetext{
${ }^{21}$ It is not surprising that the estimate of $\beta$ remains significant even with the inclusion of GDP on the right-handside of (31) since GDP per capita and road quality have a relatively low correlation across countries of 0.58 .

${ }^{22}$ See, for example, Alessandria and Kaboski (2011) for evidence across a range of goods and countries and Simonovska (2013) for evidence of price discrimination for specific products.
} 


\section{Discussion of Catalyst Goods}

According to the empirical results, catalyst consumption is associated with higher prices of relevant tradables. One advantage of the empirical specification is that the strong estimated relationship is conditional on the association between catalyst consumption and prices that is captured by the country-level fixed effects, and thus provides lower bound on the dependence of prices on catalyst goods. Since catalyst consumption is strongly correlated with income per capita, the results also provide a lower bound on the dependence of consumer prices on income per capita driven by demand complementarities. A limitation of this approach is that I can neither rule out other mechanisms nor quantify their roles because the country fixed effects capture the average dependence of prices on income per capita without distinguishing precise mechanisms. Thus it seems reasonable to infer that demand complementarities are an important source of price variation, but it is left for future work to determine precisely how important relative to other causes of the price-income relationship.

The catalyst goods examined in the empirical section are durables such as housing and public infrastructure. These goods are readily identified as catalysts for specific subsets of tradable goods and are thus amenable to an empirical investigation of the role of catalysts in generating high consumer goods prices in rich countries. However, the notion of a catalyst applies broadly to any good or service that may complement demand for other goods and services. This includes nondurable goods and services, as well as amenities for which there is not an explicit market price. Customers do not always directly pay for amenities associated with the services they purchase, but the amenities complement their demand for services. For example, customers may have higher utility from food at a restaurant if the restaurant has nice artwork, good service, and comfortable chairs. The more efficiently a restaurant can produce these complementary goods and services, the more it can charge for food of a given cost. Likewise, the availability of retail stores, and the quality of service at those stores, can complement demand for retail goods.

Finally, one can think of marketing and related sales activity as catalyst services. A number of recent papers, including Arkolakis (2010) and Gourio and Rudanko (2011), investigate the implications of marketing and sales activity on firm outcomes. The analysis above suggests that such activity may also contribute to the cross-country differences in prices if such activity increases consumers' demand. 


\section{Conclusion}

This paper proposes a new explanation to account for the high prices of tradable and nontradable consumer goods in countries with high per capita incomes. The utility consumers derive from consumer goods depends on their consumption of complementary goods. Rich countries can afford more complementary goods, which generates high (and inelastic) demand for other consumer goods. As a result, monopolistically competitive firms charge higher markups in rich countries.

The paper presents independent evidence that supports a strong role of demand complementarities in driving cross-country price differences. Prices of subsets of exported goods depend on countries' stock of relevant complementary goods, conditional on country level fixed effects and conditional on income per capita. The estimated dependence of prices on complementary goods across countries is a lower bound on the true dependence of prices on demand complementarities. Precisely quantifying the role of demand complementarities is left for future work.

\section{Appendix A}

The models presented above feature an endowed numeraire that enters the utility function linearly. This setup is chosen for its tractability and because it permits a focus on demand complementarities, rather than the marginal utility of income, as the determinant of consumers' price elasticity of demand for final goods. Here I present an alternative closed-economy setup in which the numeraire is produced by labor, rather than endowed. The utility function is also altered to permit the marginal utility of income to vary with income. ${ }^{23}$

The representative agent's utility function is defined over the catalyst $C$, the mass $\Omega$ of final goods, and a numeraire $Y$ :

$$
U=Y^{\eta}\left(C^{\alpha} \int_{\Omega} f_{\omega} d \omega-\frac{1}{2} \gamma \int_{\Omega} f_{\omega}^{2} d \omega\right)^{1-\eta}
$$

\footnotetext{
${ }^{23}$ If the model were to feature a numeraire produced by labor and a baseline utility function given by (1), the model solution would be at a corner in which the numeraire is the only good produced and consumed. A derivation of the corner solution to this alternative setup is available upon request.
} 
where $f_{\omega}$ is consumption of final good $\omega \in \Omega$. This utility function is similar to that in Chaney (2008) in that it features Cobb-Douglass preferences over a homogenous numeraire and differentiated consumer goods.

The budget constraint is

$$
w L+\int_{\Omega} \Pi_{\omega} d \omega=Y+p_{C} C+\int_{\Omega} p_{\omega} f_{\omega} d \omega,
$$

Consumer optimization with respect to $f_{\omega}$ yields the implicit demand for final good of variety $\omega$ :

$$
Y^{\eta}(1-\eta) B^{-\eta}\left(C^{\alpha}-\gamma f_{\omega}\right)=\lambda p_{\omega}
$$

where $\lambda$ is the multiplier on the budget constraint (33) and $B \equiv C^{\alpha} \int_{0}^{\Omega} f_{\omega} d \omega-\frac{1}{2} \gamma \int_{0}^{\Omega} f_{\omega}^{2} d \omega$ is the bundle of final and catalyst goods. We can obtain an expression for $\lambda$ from the first order condition with respect to $Y$ :

$$
\eta Y^{\eta-1} B^{1-\eta}=\lambda
$$

Combining the above two equations yields an explicit expression for demand for final good $\omega$ :

$$
f_{\omega}=\frac{1}{\gamma}\left[C^{\alpha}-\frac{\eta}{1-\eta} \frac{1}{Y} B p_{\omega}\right] .
$$

Production of final goods, catalyst goods, and the numeraire good are linear in labor using labor productivity $A$, which is assumed to be identical across sectors. The final goods sector is monopolistically competitive, while the catalyst and numeraire sectors are perfectly competitive. Firm $\omega$ maximizes $\Pi_{\omega}=\left(p_{\omega}-\frac{w}{A}\right) f_{\omega}$, which implies the optimal price

$$
p_{\omega}=\frac{1}{2}\left[Y \frac{1-\eta}{\eta} B^{-1} C^{\alpha}+\frac{w}{A}\right] .
$$

The price increases with $C^{\alpha}$, as in Section 2. It also increases as the marginal utility of income falls. Since $\lambda$ is decreasing in $Y$, the price of final goods is increasing in $Y$.

Given the price the resulting demand for $\operatorname{good} \omega$ is

$$
f_{\omega}^{d}=\frac{1}{2 \gamma}\left[C^{\alpha}-\frac{w}{A} \frac{\eta}{1-\eta} \frac{1}{Y} B\right] .
$$

Demand for the catalyst is derived from consumer optimization:

$$
C=\left[Y \frac{1-\eta}{\eta} \alpha \frac{F}{p_{C}} B^{-1}\right]^{\frac{1}{1-\alpha}} .
$$


Equilibrium is characterized by demand for catalysts, demand for consumer goods, and labor market clearing,

$$
L=\frac{1}{A}(\Omega f+C+Y)
$$

These conditions can be written as

$$
\begin{gathered}
C=\left[Y \frac{1-\eta}{\eta} \alpha f\left(C^{\alpha} f-\frac{1}{2} \gamma f^{2}\right)^{-1}\right]^{\frac{1}{1-\alpha}} \\
f=\frac{1}{2 \gamma}\left[C^{\alpha}-\frac{\eta}{1-\eta} \frac{\Omega}{Y}\left(C^{\alpha} f-\frac{1}{2} \gamma f^{2}\right)\right] \\
L=\frac{1}{A}(\Omega f+C+Y),
\end{gathered}
$$

where I've substituted in $w=A$ and $p_{C}=w / A$. Figure A1 shows market responses to an increase in productivity $A$. As in the baseline model in Section 2, prices of final goods are increasing in a country's wealth due to markups that increase with consumption of the catalyst good.

\section{Appendix B.}

The models in this paper use a simple linear demand curve to illustrate how an increase in complementary goods (catalysts) reduces the price-elasticity of demand for final consumer goods by shifting out the demand curve. Linearity of the demand curve is sufficient for a decrease in the price elasticity of demand in response to an increase in the complementary good, but it is not a necessary condition. This appendix derives the necessary and sufficient conditions on the demand curve under which an increase in complementary goods leads to higher markups for consumer goods.

A generic demand curve can be written $q=q(C, p)$, where $C$ is the complementary catalyst and $p$ is the price of the good. The price-elasticity of demand is decreasing in $C$ if and only if $\frac{\partial \epsilon}{\partial C}<0$, where $\epsilon \equiv\left|\frac{\partial q}{\partial p} \frac{p}{q}\right|$. We can write $\frac{\partial \epsilon}{\partial C}=-q_{21} \frac{p}{q(D, p)}+q_{2} \frac{p}{q(D, p)^{2}} q_{1}$, in which case the necessary and sufficient condition simplifies to

$$
q q_{21}>q_{2} q_{1} .
$$


Condition (39) states that any slope-increasing effects of an increase in $C$ on the demand curve must be more than compensated by a shift out of the demand curve. In the commonly used case of a constant elasticity demand curve, $q=C p^{-\epsilon}$, these two effects exactly cancel out so that $q q_{21}=q_{2} q_{1}$. As discussed in Nakamura and Zerom (2010), price-independent demand elasticities are difficult to reconcile with the data. Their estimates on coffee demand suggest that the price elasticity of demand is increasing in the price.

\section{References}

Arkolakis, Costas.,"Market Penetration Costs and the New Consumers Margin in International Trade," Journal of Political Economy, 118 (2010), 1151-1199.

Alessandria, George. and Joseph P. Kaboski, "Pricing-to-Market and the Failure of Absolute PPP," American Economic Journal: Macroeconomics, 3 (2011), 91-127.

Allen, Treb, "Information Frictions and Trade," Northwestern University, 2012.

Bergstrand, Jeffrey H, "The Heckscher-Ohlin-Samuelson Model, the Linder Hypothesis and the Determinants of Bilateral Intra-industry Trade.” Economic Journal 100 (1990), 1216-29.

Bhagwati, Jagdish N, "Why Are Services Cheaper in the Poor Countries?” Economic Journal, 94 (1984): 279-86.

Balassa, Bela. 1964, “The Purchasing-Power Parity Doctrine: A Reappraisal,” Journal of Political Economy, 72 (1964): 584-96.

Burstein, Ariel, and Nir Jaimovich, "Understanding Movements in Aggregate and Productlevel Real Exchange Rates." Unpublished Manuscript, 2012.

Chaney, Thomas, "Distorted Gravity: The Intensive and Extensive Margins of International Trade.” American Economic Review, 98 (2008), 1707-1721.

Fajgelbaum, Pablo, Gene M. Grossman, and Elhanan Helpman, "Income Distribution,Product Quality, and International Trade," Journal of Political Economy, 119 (2011), 721- 765.

Fieler, Ana Cecilia, "Non-homotheticity and Bilateral Trade: Evidence and a Quantitative Explanation." Econometrica, 79 (2011), 1069-1101.

Fitzgerald, Doireann, and Stefanie Haller, "Pricing-to-Market: Evidence from Plant-Level Prices," forthcoming, Review of Economic Studies, 2012. 
Foster, Lucia, John Haltiwanger, and Chad Syverson, "Reallocation, Firm Turnover, and Efficiency: Selection on Productivity or Profitability?" American Economic Review, 98 (2008), 394-425.

Gopinath, Gita, Pierre-Oliver Gourinchas, Chang-Tai Hsieh, and Nicholas Li, "International Prices, Costs, and Markup Differences," American Economic Review, 101 (2008), 24502486.

Gourio, Francois and Leena Rudanko, “Customer Capital,” NBER Working Paper 17191, 2011.

Hsieh, Chang-Tai, and Peter J. Klenow, "Relative Prices and Relative Prosperity," American Economic Review, 97 (2007), 562-85.

Harrod, Roy F, International Economics, London: James Nisbet \& Co, 1933.

Heston, Robert, “Dwelling Services.” International Comparison Program Book, Chapter 12, 2011.

Hummels, David and Volodymyr Lugovsky, "International Pricing in a Generalized Model of Ideal Variety," Journal of Money, Credit, and Banking, 41 (2009), 3-33.

Hunter, Linda. 1991. "The Contribution of Non-homothetic Preferences to Trade." Journal of International Economics, 30 (1991), 345-358.

Khandelwal, Amit, "The Long and Short (of) Quality Ladders," Review of Economic Studies. 77 (2010), 1450-1476.

Krugman, Paul, "Pricing to Market When the Exchange Rate Changes," in S.

W. Arndt and J. Richardson, eds., Real Financial Linkages Among Open Economies, London: MIT Press, 1987.

Krugman, Paul. 1980. "Scale Economies, Product Differentiation, and the Pattern of Trade." American Economic Review 70(5): 950-959.

Lancaster, Kelvin J., "A New Approach to Consumer Theory," Journal of Political Economy, 74 (1966): 132-157.

Manova, Kalina and Zhiwei Zhang, "Export Prices across Firms and Destinations," Quarterly Journal of Economics, 127 (2012), 379-436.

Markusen, James R, "Putting Per-Capita back into Trade Theory and Policy," Journal of International Economics, 90 (2013), 255-265.

Matsuyama, Kiminori, “A Ricardian Model with a Continuum of Goods under Nonhomothetic Preferences: Demand Complementarities, Income Distribution, and North-South Trade," Journal of Political Economy, 108 (2000), 1093-1120. 
Melitz, Marc J. and Gianmarco I.P. Ottaviano, "Market Size, Trade, and Productivity." Review of Economic Studies 75 (2008), 295-316.

Mitra, Devashish and Vitor Trindade, "Inequality and Trade," Canadian Journal of Economics, 38 (2005), 1253-71.

Murphy, Daniel P., "Why are Goods and Services more Expensive in Rich Countries? Demand Complementarities and Cross-Country Price Differences," Research Seminar in International Economics Working Paper \#636, 2013.

Nakamura, Emi and Dawit Zerom, “Accounting for Incomplete Pass-Through,” Review of Economic Studies, 77 (2010), 1192-1230.

Ottavanio, Gianmarco. I. P., Takatoshi Tabuchi. and Jacques-François Thisse, "Agglomeration and Trade Revisited," International Economic Review, 43 (2002), 409-436.

Samuelson, Paul A.,"Theoretical Notes on Trade Problems," Review of Economics and Statistics, 46 (1964): 145-54.

Simonovska, Ina, “Income Differences and Prices of Tradables.” UC Davis, 2013.

Summers, Robert, and Alan Heston, "The Penn World Table (Mark 5): An Expanded Set of International Comparisons, 1950-1988," Quarterly Journal of Economics, 106 (1991), $327-68$. 
Table 1: Consumer Goods and Household Goods by End Use

\begin{tabular}{|c|c|c|c|}
\hline End Use code & End Use & Household Good? & \\
\hline 40000 & Apparel, household goods - textile & 1 & Include towels, bed linens, curtains \\
\hline 40030 & Apparel,household goods-nontextile & 1 & Include towels, bed linens, curtains \\
\hline 40050 & Sports apparel and gear & & \\
\hline 40100 & Pharmaceutical preparations & & \\
\hline 40110 & Books, printed matter & & \\
\hline 40120 & Toiletries and cosmetics & & \\
\hline 40130 & Tobacco, manufactured & & \\
\hline 40140 & Writing and art supplies & & \\
\hline 41000 & Furniture, household goods, etc. & $\mathrm{X}$ & \\
\hline 41010 & Glassware, chinaware & $\mathrm{X}$ & \\
\hline 41020 & Cookware, cutlery, tools & $\mathrm{x}$ & \\
\hline 41030 & Household appliances & 1 & Exclude Radiators, Air Conditioners \\
\hline 41040 & Rugs & $\mathrm{x}$ & \\
\hline 41050 & Other household goods & 1 & Exclude shavers, hair dryers, cellular phones \\
\hline 41110 & Pleasure boats and motors & & \\
\hline 41120 & Toys/games/sporting goods & & \\
\hline 41140 & Musical instruments & & \\
\hline 41200 & TV's, VCR's, etc. & $\mathrm{X}$ & \\
\hline 41210 & Stereo equipment, etc. & $x$ & \\
\hline 41220 & Records, tapes, and disks & & \\
\hline 41300 & Numismatic coins & & \\
\hline
\end{tabular}

Note: The table shows consumer goods by end use classification. $\mathrm{X}$ indicates that all goods in an end use category are identified as household goods. / indicates that a subset of goods in that category are identified as household goods. 
Table 2-Coefficient Estimates from Fixed-Effects Regressions of Log Unit Values of U.S. Exports on PerCapita Electricity Consumption

\begin{tabular}{|c|c|c|c|}
\hline \multicolumn{4}{|c|}{ Dependent Variable: $\log ($ price $) / S D(\log ($ price $))$} \\
\hline \multirow[b]{2}{*}{ Regressors } & \multirow{2}{*}{$\begin{array}{c}\text { Subsample } 1 \\
(1)\end{array}$} & \multicolumn{2}{|c|}{ Subsample 2} \\
\hline & & $(2)$ & (3) \\
\hline \multirow[t]{2}{*}{ MWh per capita X Electric good } & $0.060 * * *$ & $0.066 * * *$ & 0.041 \\
\hline & $(0.018)$ & $(0.022)$ & $(0.028)$ \\
\hline \multirow[t]{2}{*}{$\log$ (GDP per capita) X Electric good } & & & 0.045 \\
\hline & & & $(0.035)$ \\
\hline \multirow[t]{2}{*}{$\log ($ quantity)/SD(Log(quantity)) } & $-0.613^{* * *}$ & $-0.614 * * *$ & $-0.614^{* * *}$ \\
\hline & $(0.010)$ & $(0.011)$ & $(0.011)$ \\
\hline Product FEs & YES & YES & YES \\
\hline Country FEs & YES & YES & YES \\
\hline R-squared & 0.29 & 0.29 & 0.29 \\
\hline \# observations & 24,061 & 23,632 & 23,632 \\
\hline \# products & 1,309 & 1,281 & 1,281 \\
\hline
\end{tabular}

Notes: Prices and quantities are normalized by their within-product standard deviation. Data source: World Bank Development Indicators and U.S. Exports by HS-10 classification. Subsample 1 includes all consumer goods which are sold to at least 10 countries, and all product-country observations with at least 100 units sold. Subsample 2 drops from Subsample 1 all electric goods with quality ladder estimates greater than the median, where the quality ladder estimates are obtained from Khandelwal (2011). Robust standard errors clustered at the product level in parentheses. $* * *, * *$, and $*$ indicate significance at the $1 \%, 5 \%$, and $10 \%$ level, respectively. 
Table 3-Coefficient Estimates from Fixed-Effects Regressions of Log Unit Values of Chinese exports on PerCapita Electricity Consumption

\begin{tabular}{lcc}
\hline \hline Dependent Variable: Log(price)/SD $(\log ($ price $))$ & & $(2)$ \\
\cline { 2 - 3 } Regressors & & $(1)$ \\
\hline MWh per capita X Electric good & $0.027^{* *}$ & $0.037^{* *}$ \\
& $(0.011)$ & $(0.015)$ \\
log(GDP per capita) X Electric good & & -0.019 \\
& & $(0.025)$ \\
Log(quantity)/SD(Log(quantity)) & & $-0.261^{* * *}$ \\
& $-0.261^{* * *}$ & $(0.012)$ \\
Product Firm City Zip FEs & $(0.012)$ & YES \\
Country FEs & & YES \\
R-squared & YES & 0.06 \\
\# observations & YES & 158,168 \\
\# product-firm-firmXlocations & 0.06 & 26,276 \\
\hline
\end{tabular}

Notes: Prices and quantities are normalized by their within-product standard deviation. Data source: World Bank Development Indicators and Chinese Exports by HS-8 classification. Robust standard errors clustered at the product level in parentheses. $* * *, * *$, and $*$ indicate significance at the $1 \%, 5 \%$, and $10 \%$ level, respectively. 
Table 4-Coefficient Estimates from Fixed-Effects Regressions of Log Unit Values of U.S. Exports on Housing Volume in European Countries

\begin{tabular}{|c|c|c|c|}
\hline \multicolumn{4}{|c|}{ Dependent Variable: Log(price)/SD(Log(price)) } \\
\hline \multirow[b]{2}{*}{ Regressors } & \multirow{2}{*}{$\begin{array}{c}\text { Subsample } 1 \\
(1) \\
\end{array}$} & \multicolumn{2}{|c|}{ Subsample 2} \\
\hline & & (2) & (3) \\
\hline \multirow[t]{2}{*}{ Housing volume $X$ Household good } & $0.057 * * *$ & $0.056 * * *$ & $0.059^{*}$ \\
\hline & $(0.022)$ & $(0.024)$ & $(0.033)$ \\
\hline \multirow[t]{2}{*}{ log(GDP per capita) X Household good } & & & -0.008 \\
\hline & & & $(0.067)$ \\
\hline \multirow[t]{2}{*}{ Log(quantity)/SD(Log(quantity)) } & $-0.508 * * *$ & $-0.507 * * *$ & $-0.507 * * *$ \\
\hline & $(0.016)$ & $(0.017)$ & $(0.017)$ \\
\hline Product FEs & YES & YES & YES \\
\hline Country FEs & YES & YES & YES \\
\hline R-squared & 0.18 & 0.17 & 0.17 \\
\hline \# observations & 9,646 & 9,125 & 9,125 \\
\hline \# products & 1,124 & 1,049 & 1,049 \\
\hline
\end{tabular}

Notes: Prices and quantities are normalized by their within-product standard deviation. Data source: World Bank Development Indicators, and U.S. Exports by HS classification. Subsample 1 includes all consumer goods which are sold to at least 10 countries, and all product-country observations with at least 100 units sold. Subsample 2 drops from Subsample 1 all electric goods with quality ladder estimates greater than the median, where the quality ladder estimates are obtained from Khandelwal (2011). Robust standard errors clustered at the product level in parentheses. $* * *, * *$, and * indicate significance at the $1 \%, 5 \%$, and $10 \%$ level, respectively. 
Table5-Coefficient Estimates from Fixed-Effects Regressions of Log Unit Values of Chinese Exports on Housing Volume in European Countries

\begin{tabular}{|c|c|c|c|c|c|c|}
\hline \multicolumn{7}{|l|}{ Dependent Variable: $\log ($ price $) / S D(\log ($ price $))$} \\
\hline Regressors & $(1)$ & $(2)$ & (3) & (4) & $(5)$ & (6) \\
\hline Housing volume $X$ Household good & $(0.009)$ & $(0.014)$ & & & & \\
\hline Housing volume (alternative measure) X Household good & & & $0.036 * * *$ & 0.027 & & \\
\hline \multirow[t]{2}{*}{$\log$ (GDP per capita) X Household good } & & $0.067^{* * *}$ & & 0.015 & & \\
\hline & & $(0.024)$ & & $(0.027)$ & & \\
\hline \multirow[t]{2}{*}{ Housing volume $X$ Luxury good } & & & & & $0.062 * *$ & \\
\hline & & & & & $(0.030)$ & \\
\hline \multirow[t]{2}{*}{ Housing volume (alternative measure) X Luxury good } & & & & & & -0.085 \\
\hline & & & & & & $(0.057)$ \\
\hline \multirow[t]{2}{*}{$\log$ (GDP per capita) X Luxury good } & & & & & 0.113 & $0.284 * * *$ \\
\hline & & & & & $(0.075)$ & $(0.067)$ \\
\hline \multirow[t]{2}{*}{$\log ($ quantity)/SD(Log(quantity)) } & $-0.237 * * *$ & $-0.237 * * *$ & $-0.237 * * *$ & $-0.237 * * *$ & $-0.236 * * *$ & $-0.236 * * *$ \\
\hline & $(0.008)$ & $(0.008)$ & $(0.008)$ & $(0.008)$ & $(0.008)$ & $(0.008)$ \\
\hline Product Firm City Zip FEs & YES & YES & YES & YES & YES & YES \\
\hline Country FEs & YES & YES & YES & YES & YES & YES \\
\hline R-squared & 0.05 & 0.05 & 0.05 & 0.05 & 0.05 & 0.05 \\
\hline \# observations & 181,170 & 181,170 & 181,170 & 181,170 & 181,170 & 181,170 \\
\hline \# product-firm-firmXlocations & 27,250 & 27,250 & 27,250 & 27,250 & 27,250 & 27,250 \\
\hline
\end{tabular}

Notes: Prices and quantities are normalized by their within-product standard deviation. Data source: World Bank Development Indicators, and Chinese Exports by HS-8 classification.

Robust standard errors clustered at the product level in parentheses. ${ }^{* * *},{ }^{* *}$, and ${ }^{*}$ indicate significance at the $1 \%, 5 \%$, and $10 \%$ level, respectively. 
Table 6-Coefficient Estimates from Fixed-Effects Regressions of Log Unit Values of U.S. Exports on Percent of Paved Roads

\begin{tabular}{|c|c|c|c|c|}
\hline \multirow{2}{*}{$\begin{array}{l}\text { Dependent Variable: } \log (\text { price }) / S D(\log (\text { price })) \\
\text { Regressors }\end{array}$} & \multicolumn{2}{|c|}{$\begin{array}{l}\text { Sample: Non-Military } \\
\text { Goods }\end{array}$} & \multicolumn{2}{|c|}{$\begin{array}{c}\text { Sample: Auto Vehicles, } \\
\text { Parts, and Engines }\end{array}$} \\
\hline & (1) & $(2)$ & $(3)$ & $(4)$ \\
\hline Percent of roads paved X New car & $\begin{array}{l}0.006 * * * \\
(0.001)\end{array}$ & & $\begin{array}{l}0.005^{* * *} \\
(0.001)\end{array}$ & $\begin{array}{l}0.003^{* *} \\
(0.001)\end{array}$ \\
\hline $\log$ (GDP per capita) X New car & & & & $\begin{array}{l}0.075 \\
(0.061)\end{array}$ \\
\hline Percent of roads paved X Auto & & $\begin{array}{l}0.000 \\
(0.000)\end{array}$ & & \\
\hline Log(quantity)/SD(Log(quantity)) & $\begin{array}{l}-0.649 * * * \\
(0.004)\end{array}$ & $\begin{array}{l}-0.649 * * * \\
(0.004)\end{array}$ & $\begin{array}{l}-0.544^{* * *} \\
(0.032)\end{array}$ & $\begin{array}{l}-0.546^{* * *} \\
(0.032)\end{array}$ \\
\hline Product FEs & YES & YES & YES & YES \\
\hline Country FEs & YES & YES & YES & YES \\
\hline R-squared & 0.33 & 0.33 & 0.24 & 0.24 \\
\hline \# observations & 332,569 & 332,569 & 8,155 & 8,155 \\
\hline \# products & 7,881 & 7,881 & 136 & 136 \\
\hline
\end{tabular}

Note: Prices and quantities are normalized by their within-product standard deviation. Data source: World Bank Development Indicators and U.S. Exports by HS-10 classification. The sample includes all non-military goods which are sold to at least 10 countries, and all product-country observations with at least $\$ 10,000$ in value. Robust standard errors clustered at the product level in parentheses. ${ }^{* * *},{ }^{* *}$, and $*$ indicate significance at the $1 \%, 5 \%$, and $10 \%$ level, respectively. 
Figure 1: Comparative Statics: Market Outcomes as Productivity Increases.
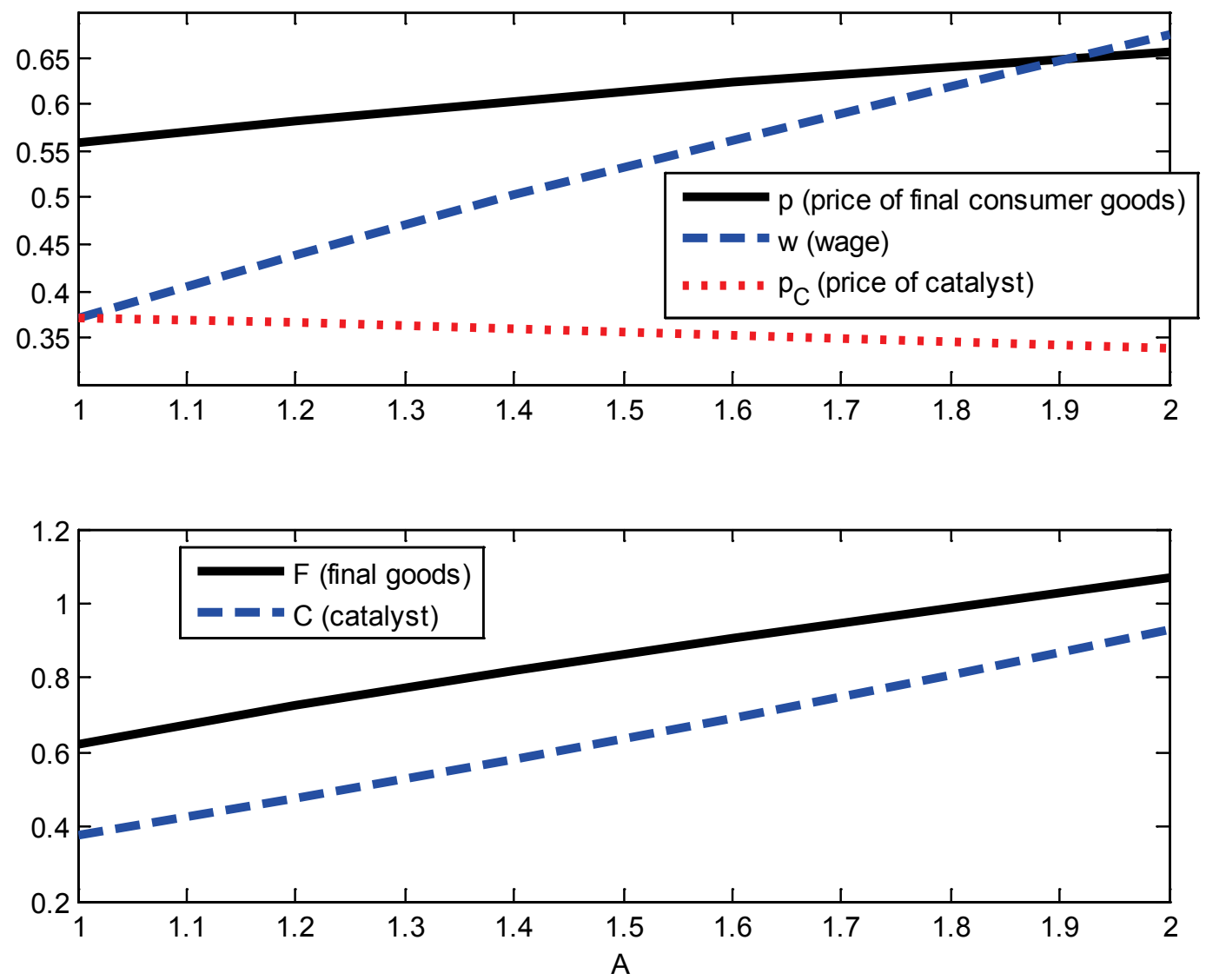
Figure 2: Effect of Productivity in $N$ on Relative Prices.
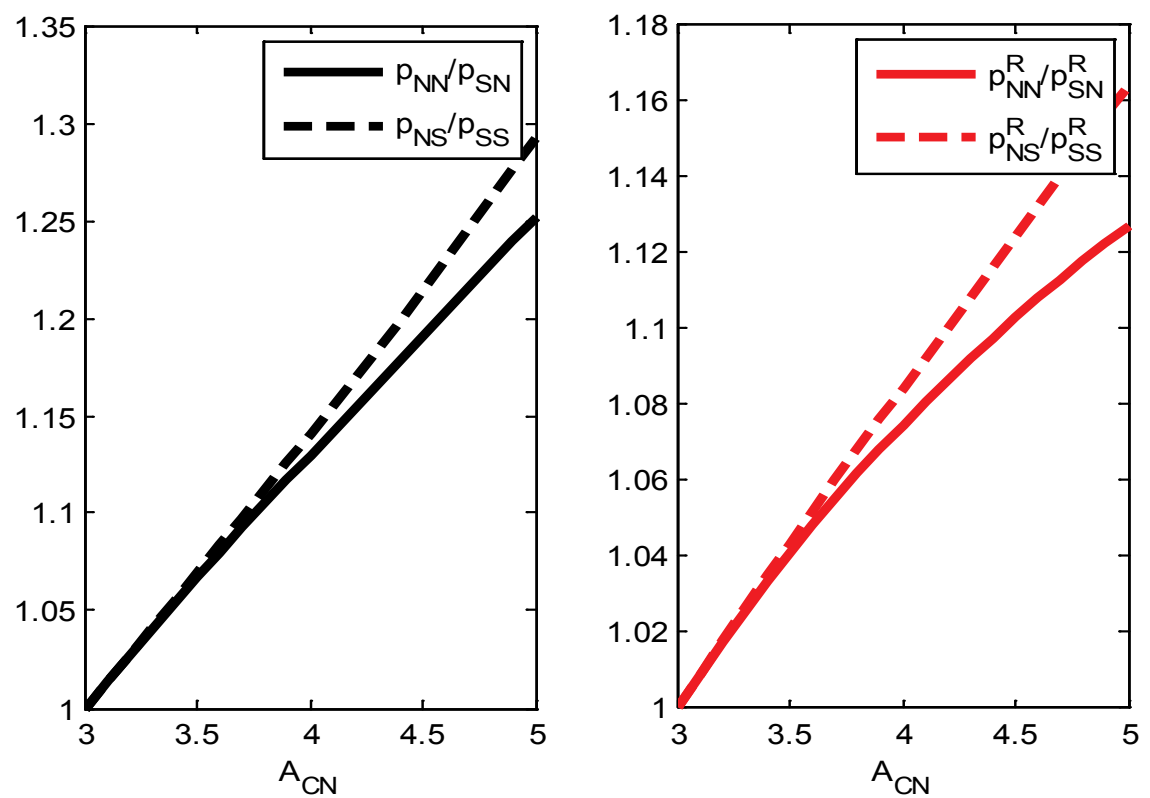

Note: The graph on the left shows the ratio of prices relative to the numeraire, while the graph on the right shows the ratio of PPP prices. See Footnote 9 for an explanation of how PPP prices are computed. 
Figure 3: Effect of Productivity in N's Final Good Sector on Prices and Quantities.
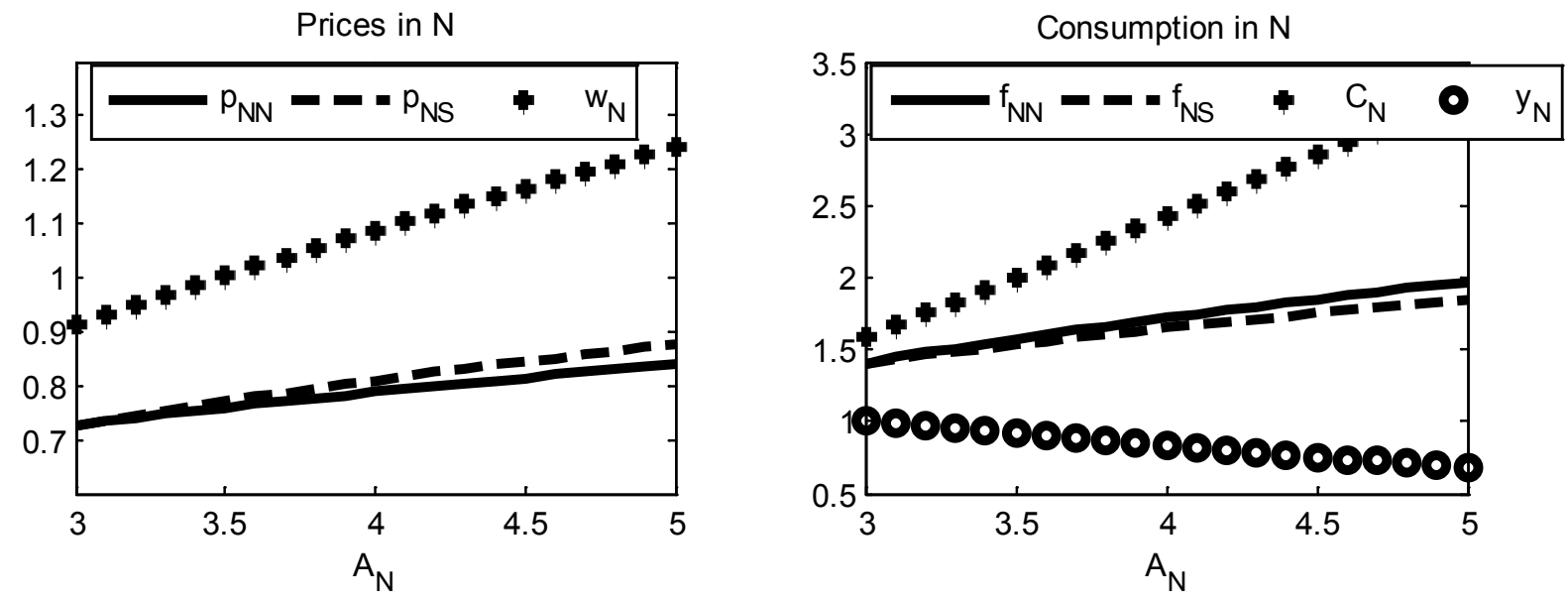

Prices in $\mathrm{S}$
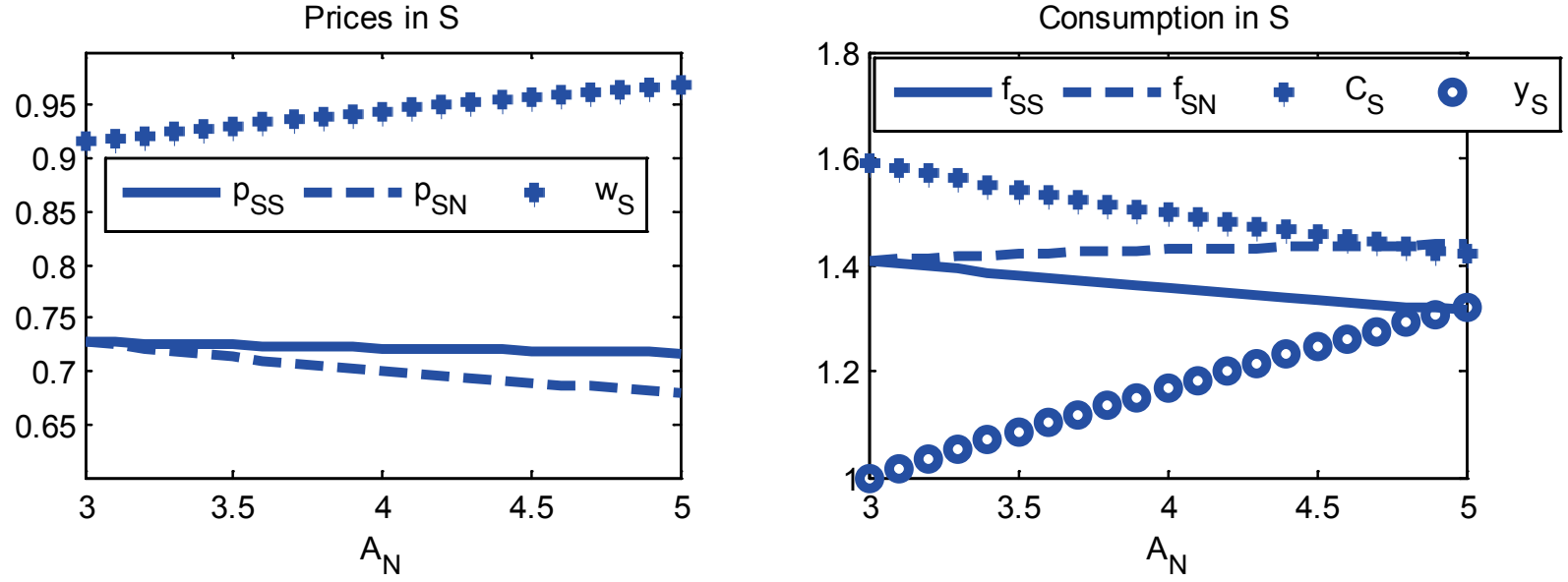
Figure 4: Effect of Productivity in $N$ on Welfare.
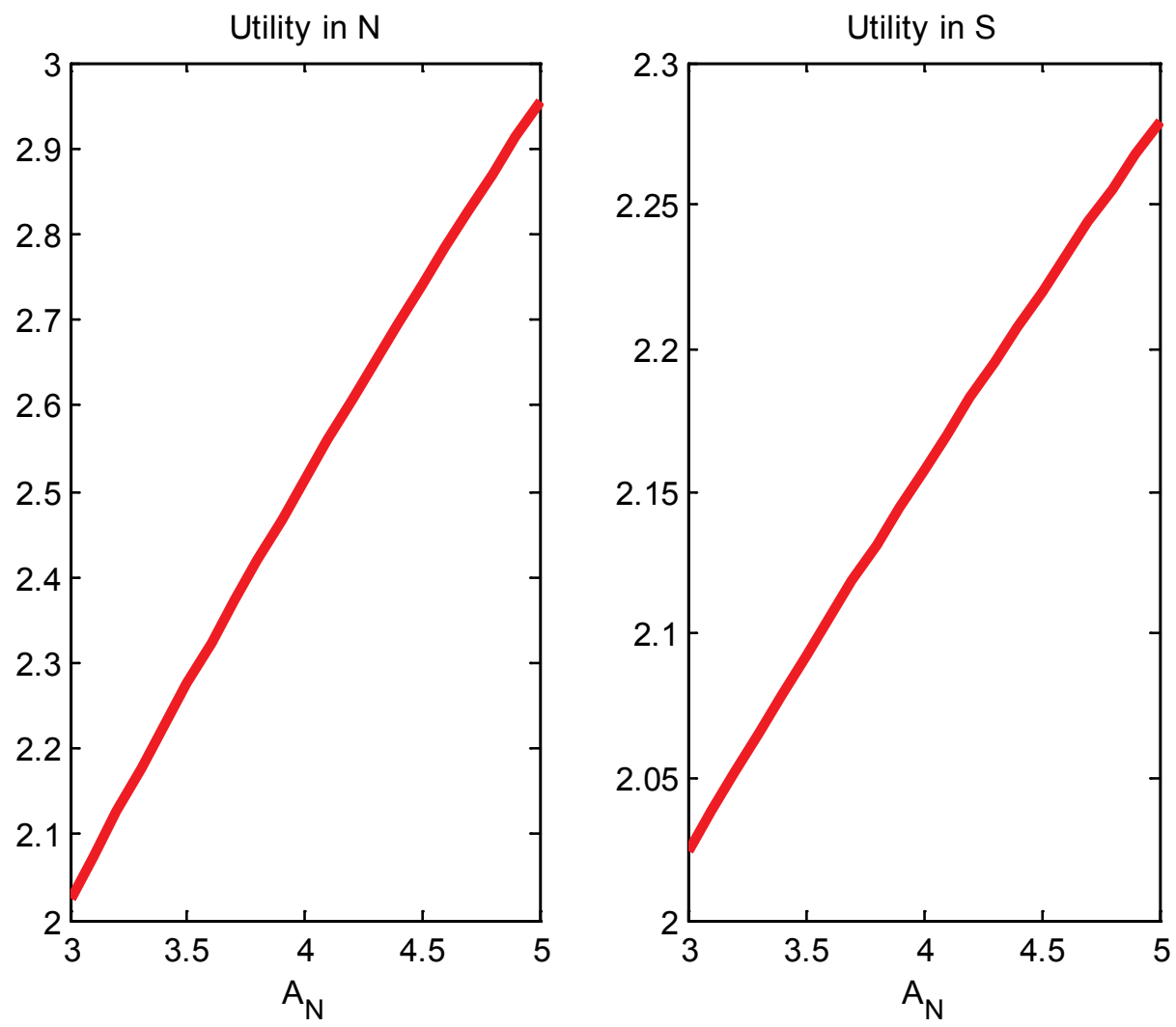
Figure 5: Effect of Productivity in $N$ on Market Outcomes in Two-Country Model with Nontraded Goods and Services.
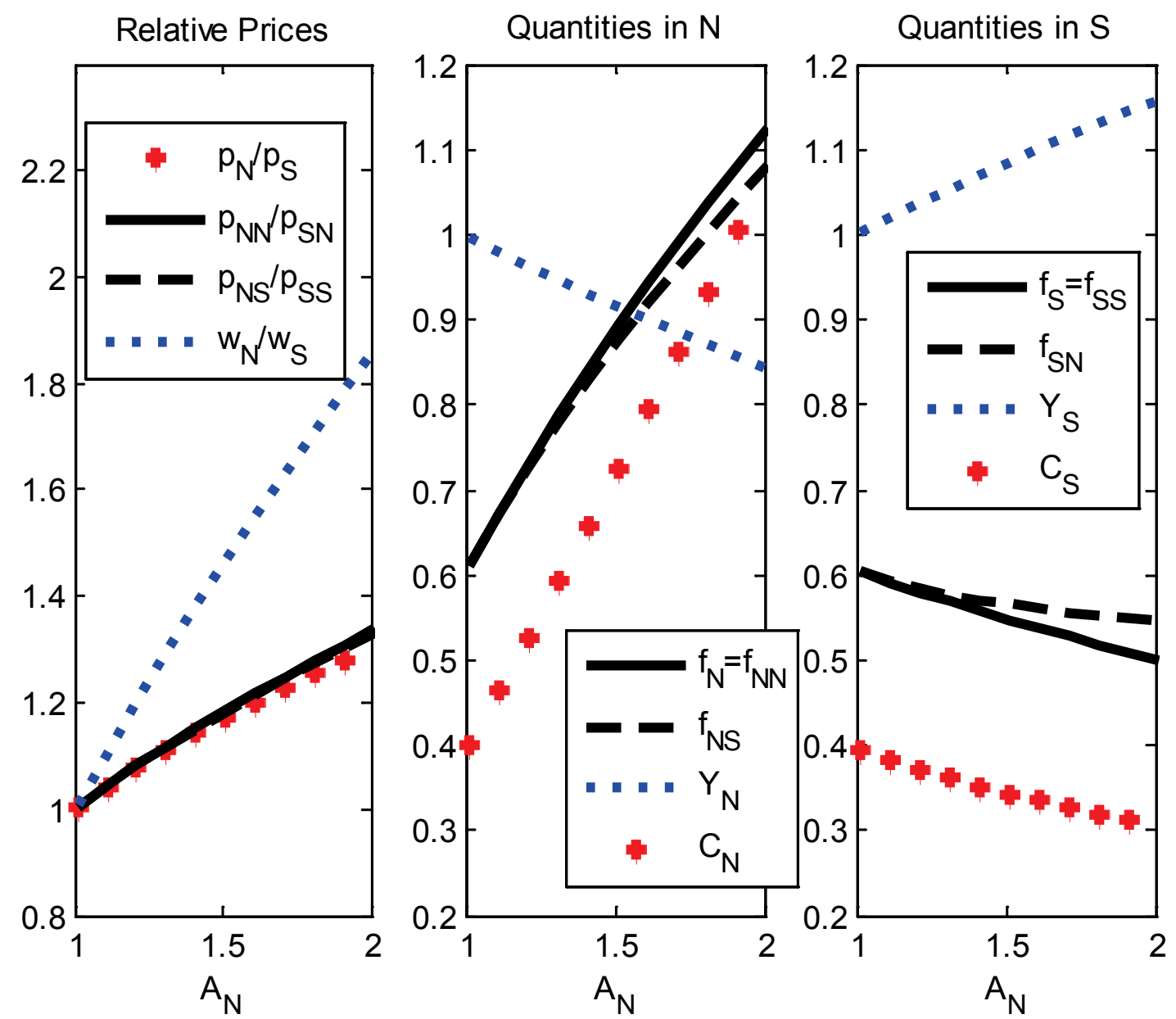
Figure A1: Market Outcomes as Productivity Increases in Model with Numeraire Produced by Labor.
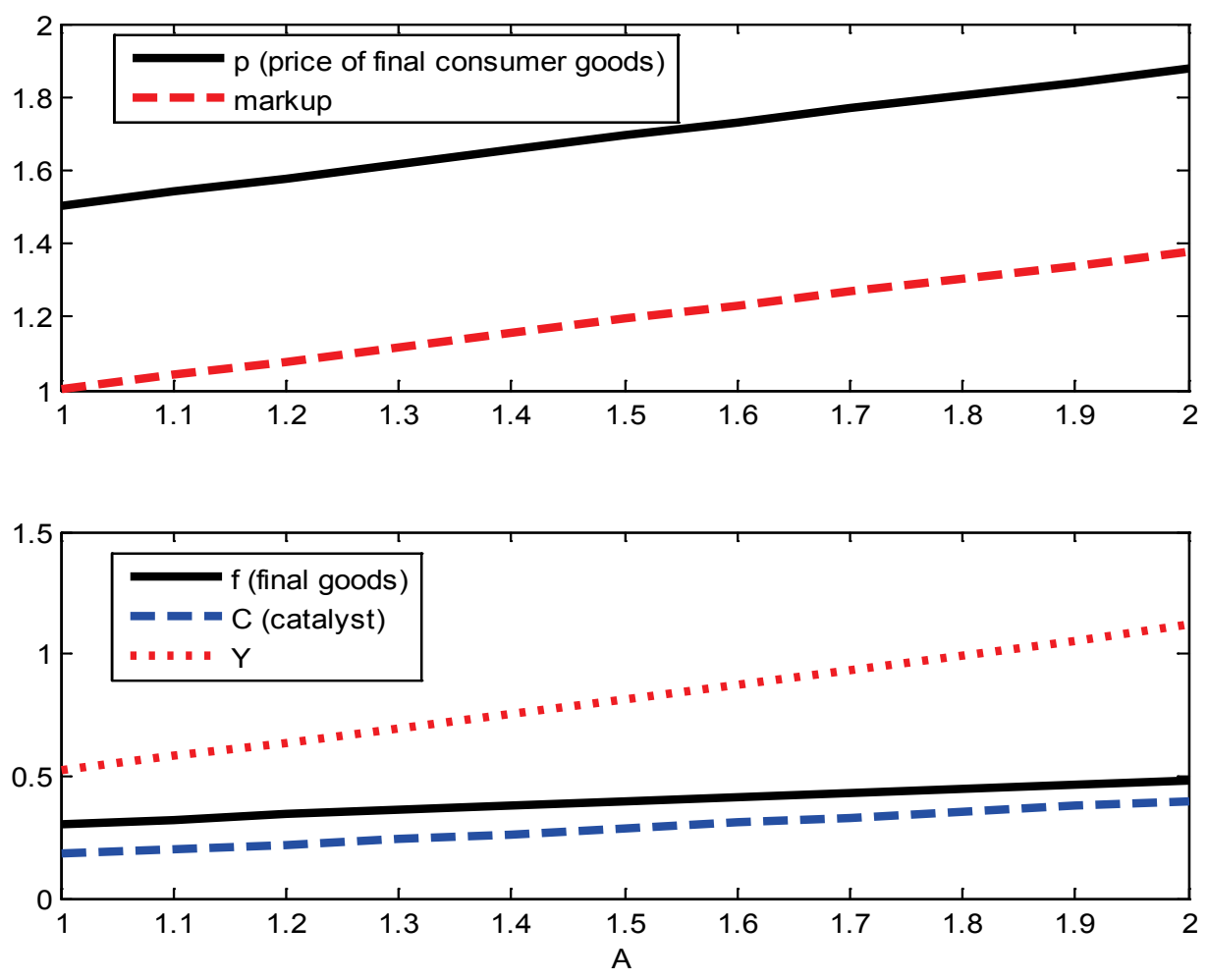